\title{
Tablet Scoring: Current Practice, Fundamentals, and Knowledge Gaps
}

\author{
Emmanuel Reginald Jacques ${ }^{1,2}$ and Paschalis Alexandridis ${ }^{2, *}$ \\ 1 Metrics Contract Services, Greenville, NC 27834, USA \\ 2 Department of Chemical and Biological Engineering, University at Buffalo, The State University of New \\ York (SUNY), Buffalo, NY 14260-4200, USA \\ * Correspondence: palexand@buffalo.edu; Tel.: +1-716-6451183
}

Received: 31 May 2019; Accepted: 22 July 2019; Published: 29 July 2019

\begin{abstract}
Oral solid dosage formulations and/or tablets have remained the preferred route of administration by both patients and health care practitioners. Oral tablets are easy to administer, they are non-invasive and cause less risk adversity. Because of the lack of commercially available tablet dose options, tablets are being split or partitioned by users. Tablet scoring refers to the breakage of a tablet to attain a desired efficacy dose and is an emerging concept in the pharmaceutical industry. The primary reason for the tablet scoring practice is to adjust the dose: dose tapering or dose titrating. Other reasons for tablet partitioning are to facilitate dose administration, particularly among the pediatric and the geriatric patient population, and to mitigating the high cost of prescription drugs. The scope of this review is to: (1) evaluate the advantages and inconveniences associated with tablet scoring/portioning, and (2) identify factors in the formulation and the manufacturing of tablets that influence tablet splitting. Whereas tablet partitioning has been a common practice, there is a lack of understanding regarding the fundamentals underpinning the performance of tablets with respect to splitting. Several factors can influence tablet partitioning: tablet size, shape, and thickness. A requirement has recently been set by the European Pharmacopoeia and the U.S. Food and Drug Administration for the uniformity of mass of subdivided tablets. For breaking ease, an in-vivo reference test and a routinely applicable in-vitro test need to be established.
\end{abstract}

Keywords: pharmaceutics; formulation; tablet manufacturing; tablet splitting; drug administration

\section{Introduction}

The pharmaceutical industry comprises fifteen major therapeutic areas: oncology, anti-diabetics, anti-rheumatics, vaccines, anti-virals, immunosuppressants, bronchodilators, dermatological, sensory organs, anti-hypertensives, anti-coagulants, multiple sclerosis (M.S.) therapies, anti-fibrinolytics, anti-hyperlipideamics, and anti-anemics [1].

To satisfy unmet medical needs across the various therapeutic areas, the pharmaceutical industries need to produce larger quantities and greater varieties of prescription drug treatments with improved efficacies [2]. The pharmaceutical industry met net sales of 800 billion dollars globally in 2018, with net profits expected to reach $\$ 1.2$ trillion over the next 5 years [3].

One of the first aspects to consider in drug formulation is the Biopharmaceutical Classification System (BCS) of the drug substance and/or active ingredient $[4,5]$. BCS classifies drug substances based on their aqueous solubility, intestinal permeability, and dissolution rate [6,7]: BCS class 1 (high solubility and high permeability), BCS class 2 (low solubility, high permeability), BCS class 3 (high solubility, low permeability) BCS class 4 (low solubility, low permeability).

The bioavailability of an orally administered drug depends primarily on its solubility in the gastrointestinal tract and its permeability across cell membranes which, in turn, depend on the chemical 
structure of the drug molecule [8]. Most drug substances used in pharmaceutical formulations are synthetic in nature with a hydrophilic part and a hydrophobic part [9]. The drug substance and/or active ingredients can be crystalline or amorphous $[9,10]$. As the crystal lattice energy of a drug compound increases, its solubility will decrease [11]. Drug substances are classified into anionic, cationic, zwitterionic and nonionic compounds [12]. Zwitterionic substances contain two polar groups of opposite polar charge, while nonionic drugs are not ionizable [12-14].

Drugs are rarely administered to a patient solely as a pure chemical entity. For clinical trial use, it is always preferred to develop a formulation. Such formulations can be updated during the later phases of the clinical trials [15]. Although the clinical trial phase drug formulations are considered experimental, it is crucial that they are administered as a formulation designed to deliver the drug in a manner that is safe, effective, and acceptable to the patient $[16,17]$. One of the most important objectives of dosage form design is to produce a product that is efficacious and will achieve acceptable therapeutic response [18]. The approach is also to develop a formulation that is robust and that is be suitable for larger scale manufacturing [19]. Most of the developed formulations never make it past clinical trials. Some fail in the clinic because of lack of exposure, lack of efficacy, adverse reaction, lack of compatibility with other co-administered drug substance, and/or high level of toxicity [20-23].

The focus of this review being practical and fundamental aspects of tablet scoring or splitting, some basic information on various routes of drug administration is provided first (Section 2), leading into a more extensive discussion on tablets (Section 3), and a detailed presentation of the current practice and regulatory framework of tablet scoring in pharmacy (Section 4). Various processes involved in the manufacturing of tablets are highlighted next, followed by information on excipients that are commonly used in tablet preparation (Section 5). It is a main thesis of this review that the: (i) formulation ingredients and (ii) manufacturing processes employed for the preparation of tablets underscore the satisfactory performance of said tablets toward scoring or splitting (Section 6), with associated benefits to both patients and health care practitioners.

\section{Overview of Drug Administration Routes}

Several routes of administration for drugs are practiced, with each route of administration encompassing a specific purpose and presenting certain advantages and inconveniences [24]. More commonly used in practice are the nine routes of drug administration listed in Table 1 and highlighted in the remainder of this section: intranasal, oral, ocular, otic, parenteral, rectal, sublingual, transdermal, and vaginal. Other drug administration methods include subcutaneous, intramuscular, intravenous, intrathecal, nebulization, topical, enteral, and endotracheal.

Table 1. Most common routes of drug administration.

\begin{tabular}{ll}
\hline Administration Route & Examples of Formulations \\
\hline Intranasal & Solutions, Sprays, Ointments, Creams \\
Oral & Syrup, Elixir, Suspension, Capsules, Tablets, or \\
Ocular & Chewable Tablets \\
Otic & Solutions and Suspensions \\
Parenteral & Solutions and Suspensions \\
Rectal & Solutions and Suspensions \\
Sublingual & Solutions, Ointments, Creams, Suppositories \\
Transdermal & Chewable Tablets and Lozenges \\
Vaginal & Ointments, Creams, Lotions, Transdermal Patches \\
\hline
\end{tabular}

\subsection{Intranasal Route}

Intranasal formulations are designed to deliver formulated drug substances into the nasal passage [25]. The nasal cavity is considered a non-invasive method to deliver drugs that are shown efficacy and that are difficult to deliver via routes other than injection [26]. The cavity is the preferred 
route of administration for drugs that present side-effects that render them undesired in the clinic; these are referred to as centrally acting drugs. For those centrally acting drugs, the pathway from nose to brain provides a faster therapeutic response. The bioavailability of intranasal drugs exhibits great level of variability [27]. In order to reduce the level of variability observed and to improve absorption within the nasal cavity, intranasal formulations should include absorption enhancers that facilitate the transport of the drug across the nasal membrane.

\subsection{Oral Route}

Oral solid tablet is a pharmaceutical dosage form containing drug substances with suitable diluents and prepared by compression. Tablet size and weight are dependent on the amount of drug substance present and the intended method of administration. Tablets are made from powdered, crystalline or granular drug substances, in combination with binders, disintegrants, controlled-release polymers, lubricants, diluents [28-31]. The compressed tablets are coated with an aesthetic polymer that are designed to mask the taste and/or to enhance tablet appearance. In some cases, the compressed tablets are coated with polymers that resist dissolution in the gastric fluid but disintegrate in the intestine [32]. Those types of polymers can also be used for tablets containing drug substances which are sensitive to the fluid in the stomach, for those which irritate the mucosa, or as a means of delayed release of the medication [32].

When there are issues achieving a target dissolution profile, the final powder blends are filled into capsules. The formulation development of preparing final powder for encapsulation is very similar to that of tablets [33]. There are two general types of capsules, hard shell and soft-shell. The hard-shell capsules can be filled with powder, granules, or pellets. Hard-shell capsules are by far the most common type. Soft-shell capsules may contain a liquid, gel like formulation.

Liquid dosage forms are administered via the oral route. Liquid dosage forms are either solutions or suspensions. Liquids can be water, alcohol, other solvent or cosolvent. Pharmaceutical approved types of flavors and sweeteners are also used in liquid formulations as taste masking agents. Liquid formulations require sterilization, addition of preservatives or a controlled $\mathrm{pH}$ environment to prevent contamination or degradation. Liquid dosage forms are high on sugar content, with added flavor and colorants. For drugs that are not soluble in water and/or other acceptable pharmaceutical solvents, liquid formulations are made into powder for constitution [34].

\subsection{Ocular Route}

Ophthalmic formulations are typically designed to provide relief at the site of administration. The ophthalmic formulations are typically presented in the forms of solutions, ointments, gels and polymeric inserts. In most ophthalmic formulations the challenge has been to increase the residence time at the site of administration [35]. The rapid washout of the ophthalmic drug that is triggered by the lachrymation of the eyes negatively influences their bioavailability [36]. To overcome this, hydroxy- propyl methyl cellulose (HPMC) is often incorporated as a viscosity enhancer to further aid in the accomplishment of sustained drug delivery [37]. Because of its polymeric nature, viscoelasticity, swelling capacity and nontoxicity, HPMC plays a crucial role in the formulation [38].

\subsection{Otic Route}

Otic formulations are designed to relieve pain and swelling inside the ear drums [39]. Otic formulations are typically presented in the forms of solutions, ointments, gels or polymeric inserts. The solvents and cosolvents used in designing these formulations are typically glycerin, propylene glycol, vegetable oils, mineral oils, or low molecular weight poly(ethylene glycols) and triglycerides. These ingredients are preferable because they provide good adhesion to the ear canal wall [40]. 


\subsection{Parenteral Route}

Parenteral dosage forms are intended for administration as an injection or infusion. Common injection types are intravenous, subcutaneous (under the skin), and intramuscular. Infusions typically are given by intravenous route. Parenteral dosage forms may be solutions, suspensions, or emulsions, but they must be sterile. If they are to be administered intravenously, they must readily mix with blood. The parenteral application requires excipients of highest quality standards. Solubilizers and cosolvents are the most widely employed excipients [41-44].

\subsection{Rectal Route}

Suppositories are an excellent dosage form for rectal administration [45]. Some of the advantages of suppositories include: the drug can be rapidly absorbed through the rectal membrane and the bioavailability of the drug is not dependent of the digestive tract. The important fact to consider during the formulation of suppositories is that the prototype is solid at ambient temperature but rapidly melts at body temperature $[46,47]$. In the case where the drug substance has low to limited solubility, various types of emulsifiers can be used to increase the solubility of the drug and to facilitate its dispersal after the suppository has melted [48]. The hardness and the shape of the suppositories play important roles: (A) the hardness is crucial for proper handling and delivery; (B) the shape provides administration comfort. The challenges of rectal suppositories are: (1) not preferred by patients, as they are inconvenient, (2) rectal absorption of most drug substances is dependent on the rectal membrane wall and that can vary significantly; in such cases, the dose becomes patient dependent, and (3) uneasiness during administration [49].

\subsection{Sublingual Route}

Sublingual formulations are solid preparations that are intended to dissolve or disintegrate slowly in the mouth [50]. They are used for systemic effect if the drug is well absorbed through the buccal lining or is swallowed. The advantages of sublingual formulations include: (1) easy administration to pediatric and geriatric patients, [51]. (2) formulation flexibility, and (3) local delivery of the drug substance over an extended period. The challenges of sublingual formulations include: (1) the drug substance taste can be overwhelming, (2) sublingual absorption of most drug substances is dependent of the buccal membrane, (3) patient excess drooling can negatively influence the bioavailability; in such cases, the dose becomes patient-dependent, and (4) slow disintegration [52-55]. Flavors and sweeteners are typically added to overcome the bitterness of the drug substances, especially for those with high intrinsic solubility.

\subsection{Transdermal Route}

Dermatological formulation forms include ointments and creams. Ointments are preparations for external use, intended for application to the skin. Typically, they have an oily or greasy consistency as they are applied to the skin. Ointments contain drug that may act on the skin or be absorbed through the skin for systemic action. Dermatological formulations produce a local drug effect either on or in the skin. Besides the specific therapeutic action of the incorporated active drugs, dermatological formulations also as serve as protectants, lubricants, emollients, or drying agents. Some dermatological formulations are intended to systemically deliver a drug. The major disadvantage of this route of administration is the low amount of drug per day that can be absorbed. This may become a significant limitation if the route is being considered for systemic therapy [56-58].

\subsection{Vaginal Route}

Vaginal formulations include solutions, powders, ointments, creams, aerosol foams, tablets and suppositories. Vaginal suppositories are the most effective and they offer several advantages: (1) generally there is less drug degradation via this route of administration compared to oral 
administration, (2) there is potential of long-term drug absorption. The latter involves a more sophisticated approach with various intrauterine devices (IUDs). Challenges of vaginal formulations include variable absorption due to $\mathrm{pH}$ variation within the cavity and patient discomfort [59].

\section{Oral Solid Dosages: Tablets}

Oral solid tablet formulations remain the preferred route of administration [60]. Oral solid dosage form drugs: (1) are less complex to formulate, (2) in general, they provide better chemical stability, and (3) are the most preferred across diverse patient populations. About one-half of all prescriptions dispensed for adolescents and adults are for tablets [60].

Upon administration, a tablet begins absorption in the gastro intestinal (GI) tract (in the lining of the mouth in some cases). Following absorption, the drug is metabolized in the liver, then enters the bloodstream. The liver can greatly affect the potency of the tablet. Other important factors that can influence absorption include: age, weight, gender, race, mental and physical conditions, compatibility with co-administered medications, contents of stomach and $\mathrm{pH}$ level in the stomach. The $\mathrm{pH}$ level in the stomach is important as it varies at fed and fasted conditions [60-63].

Tablets are available in different shapes, forms, or sizes depending on the dose [64]. The size and shape of the tablets are typically decided by the company's marketing group $[65,66]$.

The complexity of tablet formulation and manufacturing is dependent of the biopharmaceutical properties of the drug substance. The biopharmaceutical property correlates with the variation in drug concentration with time as a result of absorption, distribution and elimination [60-63]. In such case, the release profile of the drug is dependent on: drug dose, administration route, rate and extent of absorption, distribution rate, rate of elimination, and the minimum effective concentration [67-69].

Figure 1 shows the evolution of the plasma drug concentration over time after dose administration. The dotted horizontal lines show the minimum effective concentration (MEC) and the maximum safe concentration (MSC) [70]. A therapy is efficacious during the times when there is enough drug exposure in the plasma with a concentration that is above the MEC level. However, the drug exposure in the plasma should never exceed the MSC level [71].

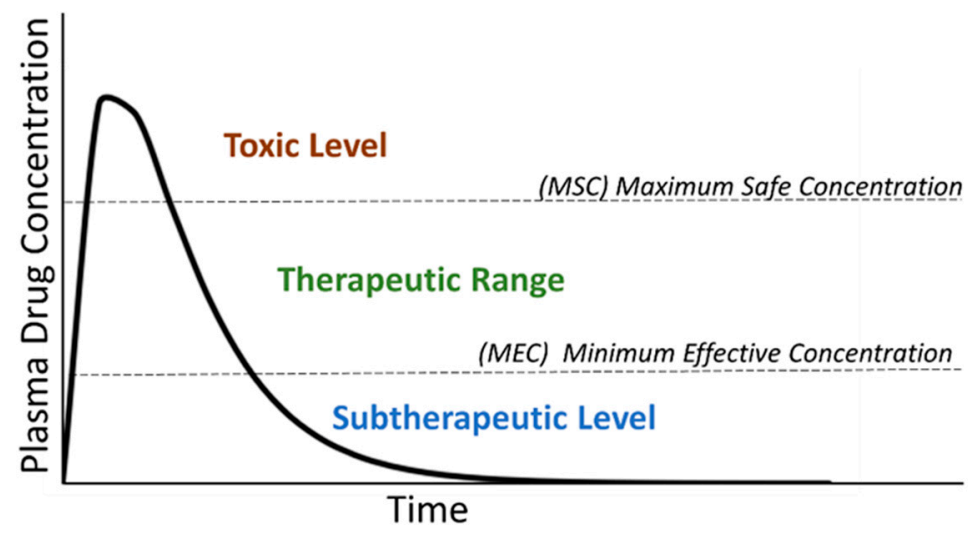

Figure 1. Drug concentration profile in plasma over time.

The biopharmaceutical properties and the physical chemistry of a drug substance play an important role in designing its formulation [19,72]. The drug substance can exist as a stable crystalline form, a metastable crystalline form or an amorphous form. It is important that the polymorph does not change during the formulation development process [73,74]. In general, drug substances without excipients are typically used in the proof of concept phase or for pharmacokinetic studies in animal models [75]. Tablets may differ greatly in size and weight depending on the intended dose and the method of administration [76]. In order to facilitate the ease of administration, several types of alteration to the final dosage form are implemented. Some of the practices involve tablet splitting/tablet scoring [77,78]. 
Tablet splitting or tablet scoring is the practice of partitioning a tablet in order to obtain a lower dose or multiple smaller doses; this is done either to reduce cost or because the commercially available tablets contain a larger dose than is required.

\section{Tablet Scoring}

An emerging concept in the pharmaceutical industry, tablet scoring refers to the breakage of a tablet to attain a desired efficacy dose. The investigation of tablet scoring is still at its infancy and its potential yet to be fully explored [79]. Several circumstances can propel the need to score a tablet $[77,80]$ including: therapeutic dose adjustment, ease of administration, cost mitigation, dose tapering or titrating, pharmacokinetic performances evaluation [81].

Tablet scoring/splitting/partitioning is most common amongst the pediatric and geriatric population. There are several challenges associated with the practice of tablet scoring. One that has garnered much attention in recent years is the lack of uniformity among the scored half tablets [82]. Such lack of content uniformity among the partitioned halves can lead to clinical risks [82].

Studies that discuss the nuances of tablets scoring have been limited. This review summarizes the work that has been done in this field and highlights some of the guidance provided by regulatory agencies. The information compiled in this review provides a basis for further research related to this field. Previously published reviews on this topic have emphasized the challenges of partitioning commercially available tablets $[77,83,84]$. Understanding and redesigning the formulation for tablet partitioning will provide opportunities to select the right excipients which will in turn help produce tablets with acceptable properties following scoring/splitting. The present review includes useful information in establishing relationships between excipients and process parameters (Appendix A) in the development of tablets, with the aim of a better subdivision performance.

\subsection{Tablet Splitting: Current Practice}

Oral solid dosage form medications, mainly tablets, are prescribed to patients as the most commonly available dosage strengths. As previously indicated, tablets contain a determined amount of drug substance that is designed to provide a desired therapeutic efficacy. Also included in tablet formulations are inert excipients, which are bulking agents, fillers disintegrants or other specialized and non-conventional excipients [85]. In general, tablets dissolve in the stomach and absorb in the lower GI track. In order to prevent tablets to dissolve in the stomach, an enteric based coat is applied. The function of this enteric coating is to provide: (1) protection to the gastric mucosa from irritation or other resulted adverse reactions, and (2) protection to the drug substance so as to prevent eventual degradation due to the $\mathrm{pH}$ environment in the stomach [86]. The decision to apply an enteric coat to tablets is typically decided during pre-formulation phase and/or upon gathering preliminary human PK data during early clinical studies.

Tablets are also available as controlled release. Controlled release tablets are designed to continuously deliver the dose over an extended period of time [86]. These types of tablets are formulated with polymers of various viscosities that are used to modulate their release profiles [86]. The administration of these tablets is less frequent compared to those of conventional formulations.

Splitting tablets in two or, in some cases, multiple fractions had been a common practice both in healthcare institutions and among patients at home. While tablet partitioning has become a common practice globally, especially in pediatric and geriatric population, this concept is still insufficiently investigated [78,84]. Many marketed tablets are embossed with a scored line to facilitate splitting [87] as shown in Figure 2. For the most part, tablet characteristics dictate the geometrical location of the scored line. 


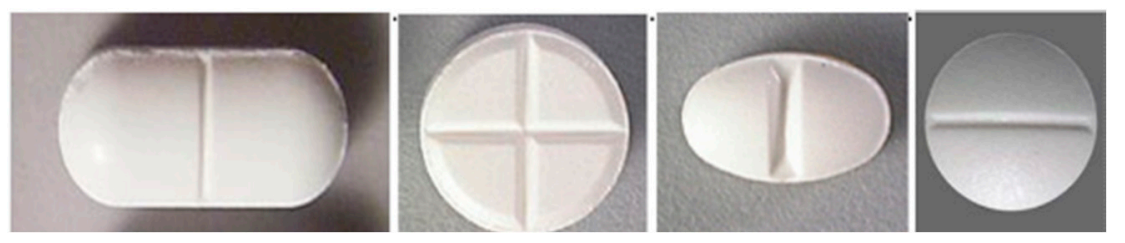

Figure 2. Different geometry scored tablets. Images are obtained from https://consumermedsafety.org. Permission obtained by Jennifer Gold at ISMP.

Tablets are generally scored for the following reasons:

(1) Facilitate administration. Several factors can influence a patient's inability to swallow a large tablet: dysphagia or difficulty swallowing, patients in moribund state, age-related psychological changes, pediatric patients $[88,89]$.

(2) Reduce cost and adjust dose. When a higher therapy dose is no longer needed, patients split tablets to save cost. The price variation among different tablet strengths is typically minimal. Requesting a higher dosage tablet strength in order to partition the tablets can be more economical to some patients. Recent studies suggest that the practice of splitting tablets has become more common because of economic hardship [90].

(3) Facilitate dose alteration. Dose alteration involves changing the marketed dose to achieve a target dose, hence, dose tapering or dose titrating [91]. Dose tapering refers to starting a medication at a high dose and slowly decrease the dose to wean the patient out of the medication. Dose tapering is typically done to prevent the effect of medication withdrawal [92]. Medical withdrawal often is associated to clinical adverse reactions. Dose titration refers to starting a medication at a low dose and slowly increasing the dose to the target level [93]. Tablet splitting provides proper dosage in cases where slow dose titration and dose tapering are necessary, particularly with medicines that control the central nervous system [94]. Recently, it has become more of a practice for pharmaceutical companies to manufacture tablets of multiple dose strengths. In some cases, a lower desired dose strength may not be available, thus the need to partition a larger dose tablets into smaller doses.

(4) Overcome changes in insurance policies. This practice aligns with cost savings; the down turn of the economy has mas made it a more common practice. Some insurance companies have denied payments for lower-strength tablets, which requires patients to obtain a larger dosage and then split the tablets [90].

Several marketed products that are commercially available at doses much higher than those traditionally used are currently being partitioned. If a marketed tablet is to be used at a prescribed dose of $12.5 \mathrm{mg}$, however, that product lowest marketed dose is $25 \mathrm{mg}$, partitioning the commercially available $25 \mathrm{mg}$ tablet is needed for the patient to obtain the intended $12.5 \mathrm{mg}$ dose. For example, patients undergoing post-myocardial infarction (PMI) often require taking a lower dose of $\beta$-blocker because of the adverse reaction associated with taking a full dose of $\beta$-blockers as observed in clinical trials $[95,96]$. This is done in order to clinically observe patient tolerability of the drug. Based on the clinical trial data, the dosage is then gradually increased to reach the appropriate dosage to be used, provided that the patient tolerability of this dose is justified [97].

Patients who are receiving therapy with a certain marketed product may require frequent dosage changes to maintain an appropriate level of effectiveness of the therapy. As such, patients may partition the tablets in order to adjust to the target dose as appropriate [98]. In certain cases, the weight accuracy after the partition is dependent on the tablet size and characteristics [99]. Smaller sized tablets, in general, introduce greater weight variation post partitioning as opposed to larger size tablets. In many instances, partition data tend to fall out of the compendial limit of variation for tablets $[99,100]$. Because there is a wider weight variation when smaller sized tablets are being partitioned, it is more 
favorable to partition larger sized tablets. However, that practice is not limited only to smaller size tablets, although the clinical data seem to favor larger size tablet $[99,101]$.

Whereas tablet partitioning offers provides the flexibility to dose adjust and/or taper as well as some financial benefits, there are several disadvantages associated with it. Some of these drawbacks are highlighted below:

- Out of specification tablets. Controlled release tablets have been designed to release the medication in a predictable manner over time [102]. To accomplish this, a variety of methods have been employed. Some methods, such as the use of coated granules, may be suitable for tablet splitting [103]. Other dosage forms, however, would have their designed features impaired by splitting. The difficulty in assessing the suitability of each controlled dosage form and the potential effect on their function makes it not favorable to partition these tablets.

- Non-robust tablets. Tablets with inadequate physical properties (e.g., low hardness, high friability) can crumble or shatter because of the brittleness property and/or low hardness values during splitting/partitioning [104]. This can compromise the desired dose and may lead to product fragmentation and wastage [104-106].

- Inadequate dose. This can present serious clinical adverse reaction, particularly in the case in which a drug of narrower therapeutic index is used [107]. Uneven split tablets may lead to administration of incorrect dose. Certain products, particularly potent compounds, are available commercially at doses of less than $1 \mathrm{mg}$. Splitting such smaller dose tablet can lead to dose inaccuracy, hence can pose serious clinical risks [108].

Controlled-release tablets should never be split. Altering these types of tablets can potentially allow immediate absorption of the full dosage, which can saturate the plasma level and lead to overdosing. This can pose a risk of serious adverse reaction [109].

Similarly, splitting opioid tablets can result in dose inaccuracies and can be harmful to patients $[110,111]$. In order to mitigate opioid abuse, several steps have been implemented by the FDA to ensure that companies reformulate their painkiller tablets in a way that will make it more difficult to alter the dose [112]. The reformulation known as opioid abuse-deterrent formulations (ADFs), involves adding a blocking agent that will counter the effect of opioids if dissolved and injected [113]. There are a few formulations for oxycodone (e.g., Targiniq ER) and other opioids that have been approved by the FDA that utilize the abuse-deterrent opioid formulation [112]. To mitigate the opioid abuse crisis, these new formulations use specialized excipients that make it difficult to crush the tablets. Another strategy of abuse deterrence involves incorporating aversion properties into the formulation $[114,115]$. For example, components that can produce unpleasant effects if the opioid tablets are manipulated [115].

Patients with complex dexterity issues, may have difficulty splitting tablets, either manually or with the use of a tablet splitter and with the use of other non-conventional objects used to partition tablets [94]. A study which focused mainly on issues pertained to the acute geriatric population revealed that more than $\frac{3}{4}$ of that population were unable to successfully partition tablets. In those cases, the challenges were to ensure that the tablets are evenly partitioned prior to administration $[94,116]$. Especially for tablets that are not clearly marked with a score line, and also tablets that lack good physical properties [117].

In some cases, tablets are partitioned unevenly, which can pose some compliance issues and minimize the reliance on the drug [104-106]. Geometrical configurations of the tablet such as shape, size, thickness and curvature play a crucial role on the performance of the score lines [76]. The depth of the score line can also be a contributing factor [76]. Performance of score lines can be defined by breaking ease, uniformity of mass of subdivided tablets and loss of mass by the subdivision [118]. For breaking ease, an in-vivo reference test and a routinely applicable in-vitro test need to be established. For the uniformity of mass of subdivided tablets, a requirement has recently been set by the European Pharmacopoeia. Loss of mass upon breaking can be limited to not more than 1\% [119]. 
Tablet scoring techniques vary from exerting force to manually breaking the tablets to using tablet sprinters devices that are designed to aide with tablets splitting [120]. Other practices involve the use of non-conventional objects such as kitchen knives [120]. All those practices present accuracy and precision challenges. Various devices available to split tablets are shown in Figure 3.

Content uniformity of the split tablets was evaluated in studies where various splitting techniques including exerting force to manually break the tablets, using a sharp object (knife) and using a tablet splitter were employed [120-124]. Tablets split by hand yielded the worst uniformity and exhibited a wider weight variation compared to those that were split using a knife or a tablet splitter. When knives were used to split tablets, a significant variation within the half tablet content uniformity was observed. When tablet splitters were used, the resulted halve tablets revealed a more uniform trend [125]. Among all the tablet splitting techniques that have been implemented, the use of a tablet splitter produced half tablets with significant less weight variation compared to the two other methods [121]. Further data have shown that formulation characteristics and manipulation techniques have great influence on the accuracy of medication modification and should be considered in off-label drug use in vulnerable populations [126-128].
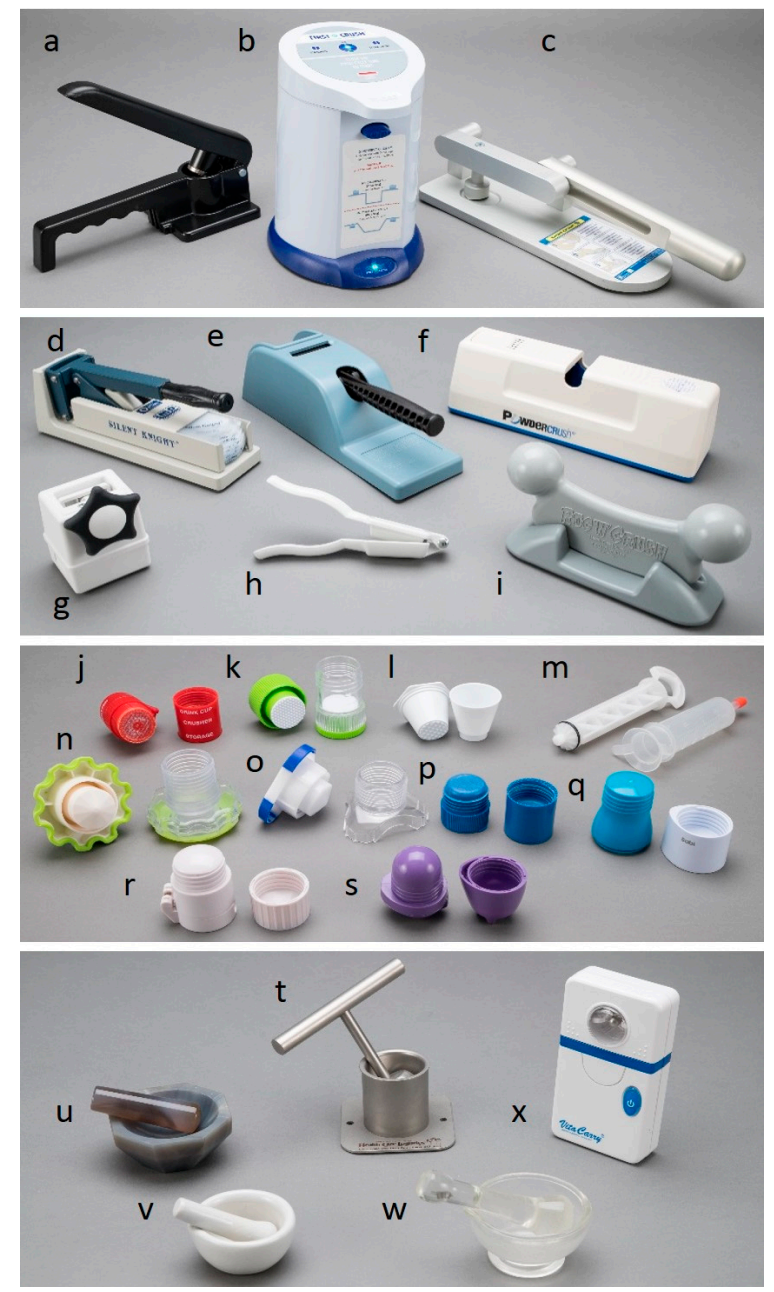

Figure 3. Various options available to split and crush tablets. Images (a) through (c) are representations of tablet crushers. Images (d) through (i) are various tablets splitters that can be used for different shape tablets that are embossed with a score line. Images (j) though (s) are tablet grinders; these are designed to grind and crush tablets to deliver finely crushed powder medication. Images (t) through (w) are tablet pulverizers that are designed to crush tablets to a fine powdered medication. They are available as ball and sockets and as motor and pestle. Image reproduced from the article [129]. Permission to include this image in this review has been obtained from PLOS One. 
Tablet physical properties such as size, curvature and thickness, and the form and deepness of the score line as well as scoring techniques can affect the effectiveness of tablet splitting [118]. To facilitate tablet splitting, recent studies have suggested the use of compression molding [130]. Compression Molding is a semi-manual operation where tablets are formed by forcing the wet granulated blend into a mold to achieve tablets of desired shapes and sizes [131]. Designing a mold cavity with a score line could in principle produce tablets that can be scored more effectively. However, this technology, while effective for proof of concept experiments, could have several limitations during large-scale production. Also, since the molded tablets are tray-dried and/or oven-dried, obtaining a desired tablet hardness and a low tablet friability may be an issue [132].

Tablet weights and uniformity of dose are interdependent. Uneven scored tablets can pose great clinical risk, especially when targeting a narrow therapeutic-toxic range [130]. By contrast, tablets with wider therapeutic indices and longer half-life are more forgiving to uneven splitting.

In a nutshell, while there are cost benefits associated with tablets splitting/partitioning, this practice is extensively used for clinical reasons. In a larger perspective, using tablet splitting to reduce costs is limited by the number of products suitable for tablet splitting [133]. The practice is largely dependent on the actions of pharmaceutical manufacturers. Factors that can influence tablet splitting practices include: (1) the number of dosages available, (2) tablet properties, (3) tablets that require specialized excipients to target a modulated release profile, and (4) storage conditions. Patients should be able to split tablets easily, either by hand or with the use of a tablet splitter. To achieve the therapeutic and economic benefits from tablet splitting, patients need to be educated on the rationale and procedures of tablet splitting [109]. Tablet splitting/partitioning has played a crucial role in modern medicine, as the ability to dose taper and dose titrate is important across therapeutic areas. Based on some accrued clinical data, some warning has been issued around the practice of tablet splitting/partitioning. According to clinical observations, approximately a third of the partitioned tablets fall outside of the recommended dosages by more than 15 percent $[79,134]$.

\subsection{Tablet Splitting: Regulatory Guidance}

To date there have been no specific regulatory requirements that govern the practice of tablet scoring. The pediatric and geriatric patient populations are the two groups that are more susceptible to this practice [135-137]. The current practice is to score the tablet to a reduced dose; the scored tablet is then administered with food and/or beverage as a surrogate in order to mask the taste of the drug substance in some cases. The challenges with that is the risk on under dosing or over dosing, where both can lead to serious adverse drug reaction [138].

The United States Food and Drug Administration (FDA) recently began to develop a new guidance for tablet scoring [139]. However, the concept of tablet scoring has not been fully investigated and the resulting data are not well understood. Across drug agencies worldwide, there are very few published standard data available to address this practice.

One important factor in analyzing a final drug product is to ensure that the composite sample of the final drug products is within specification guidelines. The guidelines are determined within the scope of the United States Pharmacopeia (USP) requirements [139]. The challenge with tablet scoring is that it introduces weights and/or uniformity variations [108]. If there are weight variations within a composite sample, the potency of that composite samples may also vary [108]. There is a direct correlation between the sample size and potency [118].

Weight and uniformity variation can expose a patient to:

(a) Drug underdose. This is a case of a patient who is continuously being exposed to a low (inefficacious) amount of a drug, hence under dosing. This can potentially create resistance to that drug, which can render the therapy ineffective. That may cause serious side effects, may prevent the drug from working properly, and/or may slow down the efficacy of the therapy [140].

(b) Drug overdose. This can be very harmful to patients, especially for high potency drugs [138]. 
The FDA guidance as it is written is similar to that of unscored tablets with added requirements to prevent risks associated with drug exposures upon administration [130].

- All scored tablets should be stable at: $5{ }^{\circ} \mathrm{C}, 25^{\circ} \mathrm{C} / 60 \% \mathrm{RH}, 40^{\circ} \mathrm{C} / 75 \% \mathrm{RH}$ for up to 90 days. Stability studies should be performed in appropriate container closures.

- Scored tablets should be stable in pharmacy dispensing containers for up to 90 days $25^{\circ} \mathrm{C} / 60 \% \mathrm{RH}$.

- The label should encompass the therapeutic dose.

- Enteric coated tablets should not be scored.

- The physical characteristic criteria for scored tablets are similar to that of whole tablets.

- Scored tablet Content Uniformity and Uniformity of Dosage unit as specified in USP 37 chapter 905.

- $\quad$ Scored tablet Water Content as specified in in USP 37 chapter 921 [65].

- $\quad$ Scored tablet Dissolution as specified in USP 37 chapter 711.

- $\quad$ Scored tablet Microbial Examination as specified in USP 61 and 62.

\section{Overview of Tablet Preparation}

\subsection{Tablet Manufacturing}

Tablets are the most desired dosage form. Normally, they are intended for the oral or the sublingual routes of administration [141]. Tablets are made from drug substances that can be crystalline or amorphous in nature. Tablets typically contain granular materials, alone or in combination with binders, disintegrants, lubricants, diluents and controlled-release polymers, in some applications. Inert excipients are mixed together with drug substances in a binary and/or ternary fashion to create a final powder blend [142-144]. Tablets are made by compressing powdered drug along with various excipients using a tablet press. There are five conventional methods available to create a final powder blend that is used in tablet manufacturing. Each of those methods utilizes different manufacturing and processing trains. Each of these tablet processing methods can influence the ability to partition tablets:

\subsubsection{Dry Granulation (Direct Compression Method)}

Direct compression consists of compressing tablets directly from powdered material without modifying the physical nature of the material. The drug substance is milled and mixed with the bulking excipients and, if necessary, with a lubricant and a disintegrant [145].

Mixing and milling are important factors to consider when splitting tablets manufactured using the direct blend process. Milling can be used to size the granules and to facilitate a homogeneous mixture [146]. Selecting excipients with comparable structure, morphology and particle size is crucial especially since there is not a granulation step involved. Uneven distribution of granule particle sizes and different granule shapes can cause granule segregation within the compressed tablet. Hence, uneven assay uniformity of half tablets [147].

\subsubsection{High Shear Wet Granulation}

This is the most widely used method, due to a greater likelihood that the granulation will meet all the physical requirements for the compression of good tablets. The main disadvantages are the number of steps involved and the time necessary to carry out the procedure, especially on a large scale [148].

Controlling the processing parameters during high shear granulation is important as there are several factors that can influence the tablet properties, and subsequently impact tablet partitioning. While excipient particle sizes and excipients of structural similarities should be controlled, their effect becomes less important since a granulation solution will be used to densify the granulation [149]. The orifice of the spray nozzle used to conduct the granulation plays a crucial role as the droplet size can impact granulation densification [150]. Granulation spray time and spray rate are also important. High spray rate can produce overwetted and over-granulated material [150]. By contrast, low spray rate can produce under granulated material [151]. Binder selection and concentration should 
be considered carefully as the viscosity of the binder solution can impact granule properties [152]. If adequate amount of binder is used, the tablets are less brittle; which can then circumvent tablet weight loss after partitioning, tablet fragmentation, tablet halves weight variation and reduce the $\%$ friability [149]. The impeller speed should also be optimized, as dispersion of the granulation solution would dictate the granulation endpoint [153]. During the drying of the wet mass, the inlet air velocity and temperature have an impact on the granule properties. Low air inlet velocity and temperature can result in oversized granule and granule hardening. High air inlet velocity can cause granule attrition and generate higher percentage of fine granules [154]. A schematic of a conventional tablet manufacturing using a high shear granulator is shown in Figure 4.

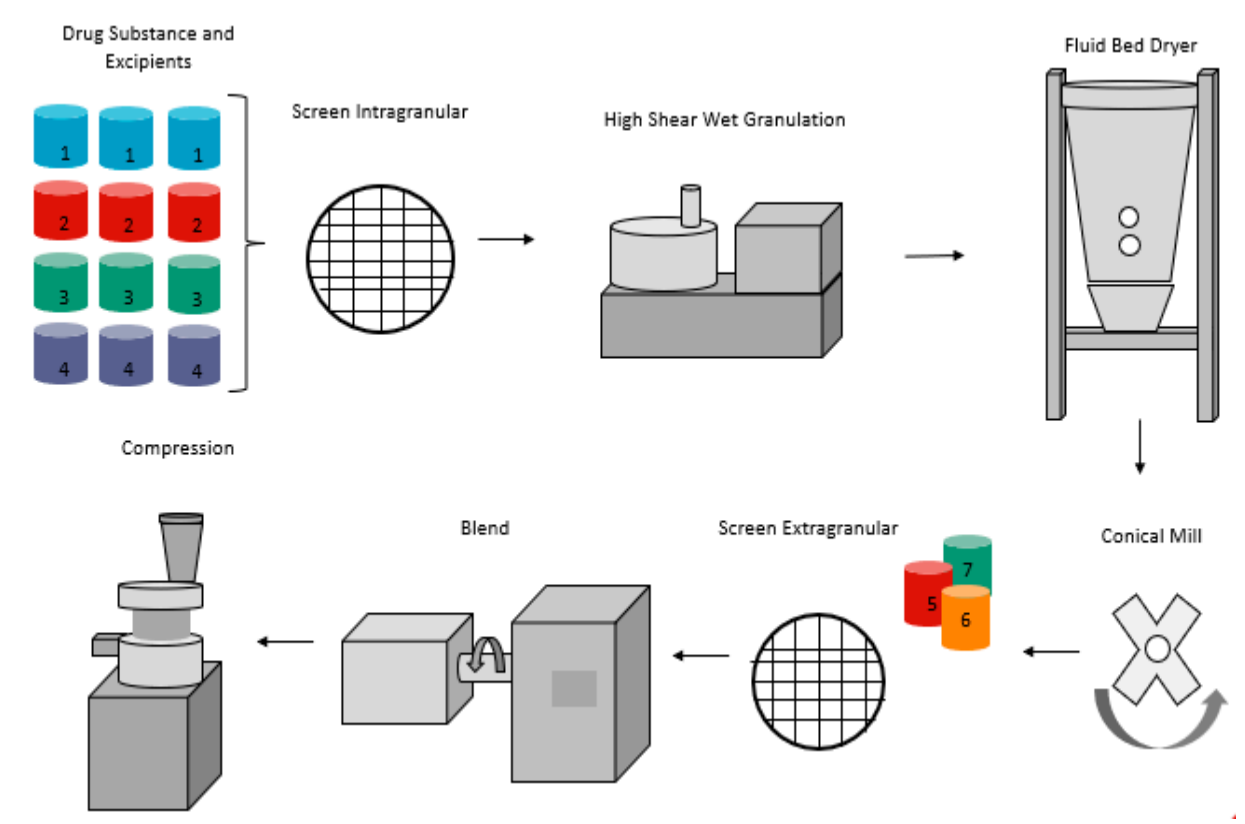

Figure 4. High shear wet granulation operation.

\subsubsection{Fluidized Bed Spray Granulation}

The fluidized bed spray unit is a multipurpose equipment used to create a final powder blend granulation. Multiple aspects of the granulation occur within the unit: mixing, granulation, and drying. It is important to determine the minimum air velocity in order to avoid bed collapse. The minimum air velocity during a fluidization process is dependent of the size, shape, density and polydispersity of the particles. The idea is that the drag hydrodynamic forces exceed the gravitational force [155-157].

Similar to high shear wet granulation, granule densification occurs within the fluid bed chamber. Thus, the structural similarities and the particle sizes of the granules are less important. The components that influence granule properties are: binder selection, binder solution addition rate, droplet size, fluidization velocity. Granules of adequate properties create robust tablets that are more amendable to tablet partitioning.

\subsubsection{Dry Granulation (Roller Compaction)}

When the drug substance is sensitive to moisture or unable to withstand elevated temperatures during drying, and when the tablet ingredients have sufficient inherent binding or cohesive properties, compaction may be used to form granules. This method is referred to as dry granulation or roller compaction [158]. Dry granulation eliminates a number of steps but still includes weighing, mixing, compacting, dry screening, dry milling, lubrication and compression [159]. The active ingredient, diluent (if one is required) and part of the lubricant are blended. For roller compaction application, one of the constituents, either the active ingredient or the diluent, must have cohesive properties. Compaction roller force/pressure is applied to the powdered material to release the air entrapped and 
to create a dense compact material. The compacted blend is milled and lubricated. Other types of unit operations that are used during a roller compaction process are blending and milling [158].

Excipients with structural similarities and comparable particle sizes should be used in order to avoid segregation during tablet compression [146]. Further, the use of excipients with good compressibility factors such as plasticizers and binder concentration is important. Since the binder will be used in the solid form, it is important to understand the required amount needed to produce tablets with good uniformity that can be partitioned without mass loss.

\subsubsection{Tablet Compression}

Following granulation, the final blend is compressed to desired tablet shapes, sizes, weights. Following tablet compression, a rotary tablet press is used to form the tablets by compressing dry granular powders to sufficient pressure to make the particles cohere. Different types of punches with appropriate cup ratio are used to compression to target the desired tablet sizes and shapes [160]. Factors that are important during tablet compression include high flowability, high compactability and low segregation. The most common challenges with tablet compression include:

(1) Capping. This typically occurs when the top part of the tablet separates from the body of the tablet. The most common reason for this issue is air entrapment. To circumvent this effect, a pre-compression force is applied to the compressed tablet, prior to applying the final compression force [161].

(2) Lamination. Lamination is often misconstrued for capping. Lamination occurs when bands or cracks are observed anywhere on the tablet rather than at the top of the tablet. This is typically process-related, especially when a large portion of fine and/or coarse granules is generated. This can also be formulation related, especially when not sufficient amount of binder is used to compress a robust tablet [162].

(3) Sticking. Sticking is caused by granulation adhesion to the punches. Several factors can influence tablet sticking: formulation (drug substance, excipient, and other components), granulation properties (granule particle size, high amount of fines and/or coarse granules), tablet design (tablet shape and sizes). Tablet-press conditions and tablet-tool properties can also influence sticking [162].

In order to effectively partition tablets, they must be free of capping, sticking and lamination. The compression force used during compression is important in order to compress tablets with adequate hardness and thickness that can facilitate partitioning [163].

\subsection{Excipients Commonly Used in Tablet Manufacturing}

In addition to the drug substance, the tablet formulation contains several inert materials that are referred to as excipients. The functions of the inert excipients are: (1) facilitate the tablet-making process, (2) bind the tablet together in order to ease compression, (3) facilitate dissolution after the tablet has been consumed, (4) aesthetic enhancement, and (5) allow for identification. Excipients play an important role in the in-vivo/in-vitro performance of the final product, and they are classified according to their functionality [164]. These excipients may be added to the drug substance as bulking agents and to facilitate the manufacturing process by adding desirable properties that are lacking in the drug substance. Excipients also play a key role in the satisfactory processing and compression characteristics of the formulation.

Depending on the intended use, tablet excipients are subdivided into two categories: (1) nonfunctional excipients that are used as processing aids to manufacture the compressed tablets, and (2) functional excipients that enhance desirable physical characteristics to the compressed tablet. Commonly used excipients and their functions in tablet formulation are listed in Table 2 and presented below. A stepwise diagram of the manufacturing process which also highlights the excipients used is shown in Figure 5. 
Table 2. Excipients used for tablet formulations.

\begin{tabular}{|c|c|c|}
\hline Excipients & Function & Example \\
\hline Diluent & Serve as bulking agent and facilitate accurate dosing. & $\begin{array}{l}\text { Sugar compounds: lactose, mannitol, dextrose, sorbitol, } \\
\text { silicate, calcium, magnesium salt, sodium chloride, } \\
\text { potassium chloride, cellulose derivatives }\end{array}$ \\
\hline Binder, compression aid, granulating agents & Facilitate tablet compression. Ensure tablet robustness. & $\begin{array}{l}\text { Natural and synthetic polymers: starch, gelatin and } \\
\text { sugars as sucrose, glucose, dextrose, and lactose }\end{array}$ \\
\hline Disintegrants & $\begin{array}{l}\text { Aid with tablet disintegration and dissolution by } \\
\text { increasing the surface area of the tablets, facilitate } \\
\text { release of drug substance. }\end{array}$ & $\begin{array}{l}\text { Compounds which swell in the presence of water: } \\
\text { Starch, cellulose derivatives, alginates and } \\
\text { crospovidone }\end{array}$ \\
\hline Glidants & $\begin{array}{l}\text { Granulation flow enhancer, aid with tablet compression } \\
\text { and eliminate particles agglomeration (anticaking) }\end{array}$ & Colloidal anhydrous silicon, silica compounds, talc \\
\hline Lubricants & $\begin{array}{l}\text { Tablet compression aid, reduce blend cohesiveness } \\
\text { characteristic during compression, reduce } \\
\text { disintegration rate }\end{array}$ & $\begin{array}{l}\text { Steric acid, salts and derivatives of steric acid, talc, } \\
\text { hydrogenated vegetable oils and PEG }\end{array}$ \\
\hline Coating agent & $\begin{array}{l}\text { Prevent tablet degradation environmental conditions } \\
\text { (Temperature, light and moisture). Serve as taste } \\
\text { masking agent, inhibit odor, facilitate administration } \\
\text { and appearance enhancer }\end{array}$ & $\begin{array}{l}\text { Natural and synthetic polymers, polymers that are } \\
\text { insoluble in acid }\end{array}$ \\
\hline
\end{tabular}




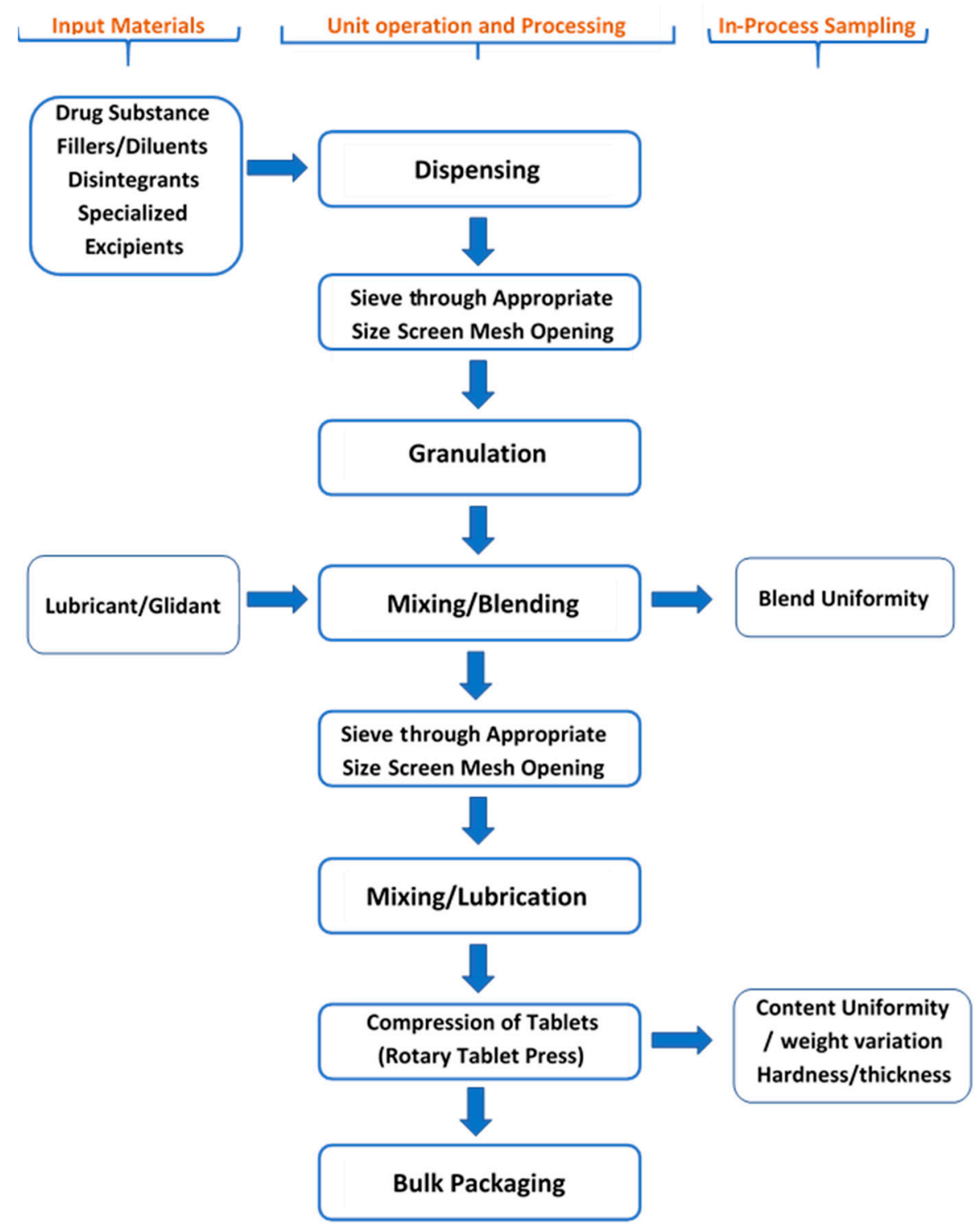

Figure 5. Process flow diagram which highlights various steps during tablet manufacturing.

\subsubsection{Diluents}

Diluents are inert substances that are added to increase the bulk of the granulation in order to facilitate tablet compression $[165,166]$. Certain diluents and or filler that are commonly used include starch, microcrystalline cellulose (MCC), mannitol, lactose, sorbitol, sucrose, dicalcium phosphate dihydrate (DCP). When present in sufficient quantity, diluents can influence the tablet properties. For example, lactose should not be used in combination with amine bases or amine salts [167] as the resulting tablet can be subjected to discoloration and degradations [167]. In a study that was conducted using placebo tablets manufactured using MCC and DCP, it was noted that MCC produced less uniform and less dense tablets compared to those produced with DCP [149]. Tablets manufactured with elastic diluents such as starch and DCP are more amenable to partitioning that those manufactured with plastic materials such as microcrystalline cellulose and lactose [168]. Crystalline lactose is considered a brittle material because of its susceptibility to fracture when stress is exerted $[169,170]$. Crystalline lactose exhibits poor compaction property and limited binding effect compared to other conventional excipients [171]. However, amorphous lactose (spray dried lactose) undergoes plastic deformation [170]. Amorphous lactose exhibits better binding ability and compressibility compared to its crystalline form [170]. An appropriate ratio of both forms of lactose can be crucial in designing 
a formulation for tablets that are amenable for scoring. While crystalline lactose can enhance the breakability of the tablets, amorphous lactose promotes good binding properties [170].

\subsubsection{Binders}

Binders are used to promote cohesive qualities to the powdered material to insure tablet robustness [166,172,173]. Binders are also used to promote granule hardness and size [172]. Commonly used binders include: starch, gelatin, and sugars as sucrose, glucose, dextrose, and lactose. Natural and synthetic gums which have been used include acacia, sodium alginate, carboxymethyl cellulose, methyl cellulose, poly(vinyl pyrrolidone) [174]. Other agents which may be considered binders under certain circumstances are poly(ethylene glycol) (PEG), ethyl cellulose, waxes, water and alcohol. The quantity of binder used has considerable influence on the characteristics of the compressed tablets [175]. The use of excessive amount of binders can influence tablet compression and tablet disintegration [176]. Binders can be used both in a solution form and in a dry form, depending on the chemical properties of the other ingredients, the method of preparation, and the unit operations used. Binders are more effective when applied to the powder formulation in solution [177]. Two commonly used binders, hydroxypropyl cellulose (HPC) or poly(vinyl pyrrolidone) (PVP) were evaluated in a study wherein MCC, DCP, and a combination of MCC and DCP were used as filler. Neither HPC nor PVP were shown to affect the partitioning of tablets containing DCP as diluent. Tablets manufactured with MCC and HPC showed better accuracy when partitioned, as opposed to those manufactured with a diluent that contained an equal amount of MCC and DCP. This was attributed to the similar structures of HPC and MCC, which facilitate the tablets partition [149].

\subsubsection{Lubricants}

Lubricants play multiple important functions in tablet manufacture [178,179], including: (1) inhibiting sticking and adhesion of the tablet granulation or powder to the faces of the punches or to the walls, (2) reducing inter particle friction, (3) facilitating the ejection of the tablets from the die cavity, and (4) promoting the flow of granulation or/or powdered materials by reducing friction among particles.

The commonly used lubricants include: talc, magnesium stearate, calcium stearate, stearic acid, sodium stearyl fumarate, hydrogenated vegetable oils and PEG [160]. Most lubricants, with the exception of talc, are used in concentrations less than $1 \%$. When talc is used as lubricant in a formulation, a concentration of approximately $5 \%$ is required to ensure effectiveness [180]. Lubricants are in most cases hydrophobic materials. The use of excessive amounts of lubricants in formulation can (1) result in poor tablet disintegration, (2) delayed dissolution of the drug substance and (3) influence tablet compression $[178,181]$. Excessive amount of lubricant used in a formulation can affect the dissolution of halves tablets [182].

\subsubsection{Glidants}

Some lubricants play the role of glidant in the formulation. Glidants are used to promote powder flow by reducing interparticle friction and cohesion [183]. Glidants are often used in combination with lubricants as glidants are not able to reduce die wall friction. Examples of glidants include fumed silica, talc, and magnesium carbonate [184].

\subsubsection{Disintegrants}

Disintegrants are added to the formulation to facilitate tablet dissolution and/or disintegration following administration $[185,186]$. The commonly used disintegrants are classified chemically as starches, clays, celluloses, and cross-linked polymers. Disintegrants in the presence of water swell, which then ruptures the tablet matrix [187]. In most formulations, starch is used at a concentration of approximately $5 \%$. In cases where a more rapid disintegration is required, the concentration of disintegrant used may increase [188]. Disintegration time and the amount of disintegrant used are 
interdependent: as the concentration of disintegrant increases, disintegration time also increases. Conversely, as the concentration of disintegrant decreases, disintegration time decreases. Other types of disintegrants that are known as "super disintegrants" such as croscarmellose sodium, crospovidone and sodium starch glycolate are also used in the pharmaceutical industry, particularly when slow tablet disintegration time is an issue [189]. These super disintegrants are effective at a concentration range $2-4 \%$. During tablet formulation, disintegrant is mixed with the active ingredients and diluents prior to granulation. In some cases, it may be advantageous to divide the disintegrant into two portions, the first to be added to the powder blend prior to granulation, and the other portion to be added post granulation with the lubricant, prior to tablet compression [189]. The reason for incorporating disintegrants in this manner is twofold: (1) the portion added post granulation helps with the rapidly break down of the tablet to granules, and (2) the disintegrant added during the pre-granulation step aids to break down the granules into smaller particles. While disintegrants are effective for tablet dissolution, if they are not well distributed within the compressed tablet, dissolution-related issues may arise, as the dissolution criteria for split portioned are the same as the finished product criteria for unpartitioned tablets.

\section{Tablet Scoring: Challenges and Opportunities}

Tablet splitting can lead to medication errors. One of the main reasons is that the tablets may not have been partitioned into the appropriate dosage. This can lead to overdose or underdose.

Other factors to take into consideration include:

(a) Lack of drug substance uniformity with a single tablet. Although a tablet may fall within specified specification of dosage strength, the active ingredient may not be equally distributed within that tablet. Research has revealed that halves of partitioned tablets may contain different concentration of actives [190]. This was typically observed when a drug substance of wide particle size distribution was used. Researchers have studied the effect of drug content uniformity only as variation in half tablet weights [190]. However, there are not enough data to support the in-vitro effect of the drug content of half tablets [191,192].

(b) Non-conventional shaped tablets. Certain tablet shapes may be difficult to partition, since the geometry of the tablet plays a crucial role in positioning the embossing scored line in the tablet [168].

(c) Fragments or crumble tablets. This issue is related to the lack of robust tablet physical property. The right selection of excipients can circumvent the fragmentation issue [193].

The current available literature focuses on the challenges of splitting scored tablets [116,194-196]. However, an important concept that does not garner much attention in the literature is the influence of granule and tablet properties on the practice of splitting tablet. The physical properties of the tablets, such as weight, thickness, hardness, friability, design and shape, are not well understood as they can influence the splitting effectiveness of tablets [197]. Selected excipients such as binders can influence mass loss, mass variation, and tablet fragmentation, and can increase brittle factor and therefore mitigate friability [198]. Because of the intricacy of designing a tablet formulation and process, it is important to consider not only excipient selections and their functions, but also the unit operations [150], particularly for processing steps that involve altering the characteristics of the excipient and drug substance. Tablet compression plays an important role, as that final step may in some cases dictate the effectiveness of splitting a tablet [99].

We discuss below the factors that can potentially influence tablet scoring. These factors are identified here on the basis of knowledge of tablet formulation, as there have been no published studies available that explicitly address these issues. The factors that are important to consider when designing a formulation suitable for tablet scoring are highlighted in Figure 6. 


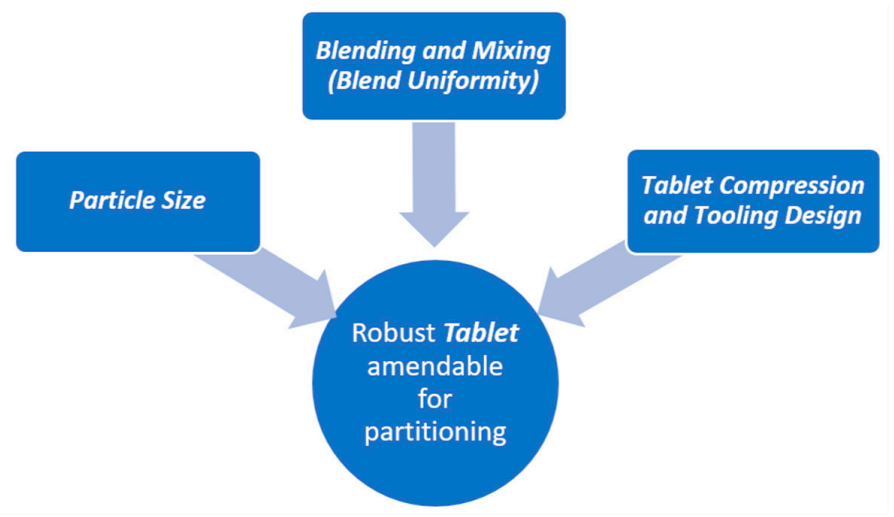

Figure 6. Factors to consider for tablet formulations in order to facilitate proper splitting.

(1) Particle Size

Particle size can affect granule flow properties [199], which can influence tablet weight variation [200]. Particle size can cause powder segregation, which can affect blend uniformity [124]. Segregation typically occurs during blend or granulation discharge [201]. Several studies have shown data in which segregated blends were evaluated using a segregation tester. The data revealed significant variability in the blend average particle size granules, confirming the evidence that particle size influence segregation [202-204]. To overcome the issue of segregation in the final blend, and to reduce the risk of poor content uniformity, it is preferable to used excipients having similar particle sizes $[205,206]$.

When there is a greater disparity in the particle size of the granulation components, segregation effects can happen making homogenous mixing difficult $[159,206]$. Segregation occurs as a result of differences in particle size, density, and structural identities of the materials used.

In the pharmaceutical industry, a conical mill (or conical screen mill) is often used to reduce the size of material in a uniform manner [207]. Sieves of different screen mesh opening are used to target the desired granule particle size [208]. Size reduction is a step that is commonly used after the granulation step to eliminate the oversize granules [209,210]. For formulations that are designed for tablet splitting, this step plays a crucial role.

(2) Blending and Mixing (Blend Uniformity)

The uniformity of a powder blend is dependent on the excipients used in the formulation and the mixing approach. Mixing is an energy consuming process which produces a random distribution of particles [211]. Poor blend uniformity can potentially produce tablets with poor content uniformity [212].

The efficiency of the mixer dictates the uniformity of the blend. Mixer efficiency is dependent on the following factors: type of mixer used, operating speed, mixing time, blend volume. Particle size, shape, density, and cohesively can also influence mixing [213].

Mixing involves the following steps:

- Convective movement of the particles from various location within the mixer [214].

- Shear movement, which is the cascading effect of the particles within the mixer [215].

- Diffusive movement of the particles as a result of increasing mobility [216].

Blend uniformity is an important factor to consider when developing a formulation suitable for tablet splitting. Blend uniformity ensures content uniformity within the tablets [212]. For tablet splitting it is important to have homogenous distribution of the drug substance in the powder blend, to ensure content uniformity in the split tablets.

(3) Tablet Compression and Tooling Design

Powder segregation should be controlled during tablet compression [160] Discharging the powder blend from the tote to the hopper tablet press introduces powder transportation effects. During the 
transport of powders, there is a constant migration of particles. Due to differences in trajectories of particles with different masses and/or sizes, these particles will be separated during transportation [217]. The shape of the particles also plays an important role during this type of segregation process [218]. Special precautions must be taken during handling of these powders by reducing the transportation velocity or the falling height segregation is minimized [217]. In order to overcome this effect, a valve is designed and placed with a certain angle at the junction of the mixer to the hopper of the tablet press [219].

The speed of the turret can introduce percolation effect where gravity causes smaller particles to move into the voids between larger particles, due to relatively larger differences in particle sizes [220].

The tablet press turret and feeder speed should be optimized in order to control powder vibration. Smaller sized particles will gradually move under the bigger sized particles, leading to a separation between differently sized particles [221].

In addition, tablet compression forces should be controlled in order to produce tablets with physical properties that are amenable for scoring [222]. Tablet splitting effectiveness is dependent on the following tablet properties.

- Hardness (good breakability will not crumble during splitting)

- Thickness (bulkier tablets can be difficult to split)

- Good friability (tablets are not brittle and do not loose mass during splitting)

Finally, tablet tooling design is also important [223], as tooling geometry and the depth of the debossed score line influence the ability to effectively score tablets.

Ineffective, tablet splitting may result in the administration of an inaccurate dose, which can be of significant risk if the split medication is a narrow therapeutic index medication. Several studies have reported weight differences among partitioned tablets [224]. Numerous studies have assessed drug content uniformity only as a variation in half tablet weights [224,225]. However, very few studies have explored the in-vitro drug content of half tablets. The current United States Pharmacopeia (USP) guidelines for drug content of split tablets are loosely defined.

\section{Conclusions}

Tablet scoring refers to the breakage of a tablet in order to attain a desired dose efficacy. Tablet scoring provides benefits regarding dose flexibility, ease of administration and cost mitigation. This practice is more common among the pediatric and geriatric patient populations.

Tablet scoring is an emerging concept in the pharmaceutical industry, however, the nuances of tablet scoring are not well understood. Because of the lack of available data to address the complexity of this practice, patients and health care practitioners are confronted with half tablets that lack weight and uniformity accuracy. This can pose adverse reaction concerns with clinicians, particularly in cases where higher potency tablets are used.

Available regulatory guidance on tablet scoring is not well defined across drug agencies worldwide. The guidance as it is written is similar to that of unscored tablets. The added requirement is to prevent risk associated with drug exposures. The stability of the scored tablets at room condition for up to 90 days should be investigated too account for possible impurities and/or degradation.

In order to overcome the issues associated with tablet scoring, the design of the formulation has to be well thought out. The selection of excipients with appropriate chemical and physical attributes is crucial. The processing parameters are also important, as some of the methods currently used can potentially modify the physical characteristic of the excipients. The use of compression tooling with adequate debossing is important, as the geometrical position of the score line can influence the partitioning of the tablets.

This review aims to highlight the current state of knowledge in the field and provide an impetus toward further studies on the fundamentals underlying tablet scoring. 
Author Contributions: P.A. and E.R.J. conceived this review. E.R.J. did most of the writing. P.A. provided guidance throughout this project, and edited drafts.

Funding: This research received no external funding.

Acknowledgments: Emmanuel Reginald Jacques is grateful to Mayne Pharma for allowing use of the facility to work on this project.

Conflicts of Interest: The authors declare no conflict of interest.

\section{Appendix A}

Table A1. Tablet Processing Parameters.

\begin{tabular}{|c|c|c|}
\hline Unit Operation & Process Parameter & Physical Properties \\
\hline Mixing & $\begin{array}{ll}\text { - } & \text { Type and geometry of mixer } \\
\text { - } & \text { Order of addition } \\
\text { - } & \text { Mixer load level } \\
\text { - } & \text { Number of rotations (time and speed } \\
\text { Agitang bar (on/off pattern) }\end{array}$ & $\begin{array}{l}\text { Blend uniformity } \\
\text { Particle size distribution } \\
\text { Bulk/tapped density } \\
\text { Moisture content } \\
\text { Flow properties }\end{array}$ \\
\hline Milling & $\begin{array}{ll}\text { - } & \text { Impact/cutting/screening mills } \\
\text { - } & \text { Mill type } \\
\text { - } & \text { Speed } \\
\text { - } & \text { Blade configuration and type } \\
\text { - } & \text { Screen size and type } \\
\text { - } & \text { Numbering rate } \\
\text { - } & \text { Feed rate } \\
\text { - } & \text { Nozzle pressure } \\
\text { - } & \text { Classifier }\end{array}$ & $\begin{array}{l}\text { Particle size } \\
\text { Particle size distribution } \\
\text { Particle shape } \\
\text { Bulk/tapped density } \\
\text { Flow properties } \\
\text { Polymorphic form }\end{array}$ \\
\hline $\begin{array}{l}\text { High Shear Wet } \\
\text { Granulation }\end{array}$ & $\begin{array}{ll}\text { - } & \text { Pre-binder addition mix time } \\
\text { - } & \text { Impeller speed, configuration, } \\
\text { - } & \text { Choppeation } \\
\text { - } & \text { Spray nozzle type and location } \\
\text { - } & \text { Binder fluid temperature } \\
\text { - } & \text { Binder addition rate and time } \\
\text { - } & \text { Post-granulation mix time } \\
\text { - } & \text { Bowel temperature }\end{array}$ & $\begin{array}{l}\text { Power consumption (process control) } \\
\text { Blend uniformity } \\
\text { Flow } \\
\text { Moisture content } \\
\text { Particle size and distribution } \\
\text { Granule strength and uniformity } \\
\text { Solid form }\end{array}$ \\
\hline Fluid Bed Granulation & $\begin{array}{ll}\text { - } & \text { Mixing time } \\
\text { - } & \text { Spray nozzle } \\
\text { (type/quantity/pattern/configuration) } \\
\text { - } & \text { Method of binder addition } \\
\text { - } & \text { Binder fluid temperature } \\
\text { - } & \text { Binder fluid addition rate and time } \\
\text { - } & \text { Inlet air flow rate, } \\
& \text { volume, temperature, } \\
\text { - } & \text { and dew point } \\
\text { - } & \text { Exhaust air temperature, flow } \\
\text { - } & \text { Filter properties and size } \\
\text { - } & \text { Shaking intervals } \\
\text { - } & \text { Product temperature } \\
\text { - } & \text { Inlet air volume, temperature } \\
\text { - } & \text { dew point } \\
\text { - } & \text { Exhaust air temperature, flow } \\
\text { - } & \text { Filter properties }\end{array}$ & $\begin{array}{l}\text { Granule size and distribution } \\
\text { Granule strength, and uniformity } \\
\text { Particle size } \\
\text { Flow } \\
\text { Bulk/tapped density } \\
\text { Moisture content } \\
\text { Residual solvents }\end{array}$ \\
\hline
\end{tabular}


Table A1. Cont.

\begin{tabular}{llll}
\hline Unit Operation & \multicolumn{1}{c}{ Process Parameter } & \multicolumn{1}{c}{ Physical Properties } \\
\hline & - Inlet air volume, temperature & \\
& - & \\
& - & Exhaust air temperature, flow & Moisture content \\
& - & Filter properties & Particle size and distribution \\
& - Shaking intervals & Granule strength and uniformity \\
& - & Product temperature & \\
& - Total drying time & \\
& & \\
\end{tabular}

Table A2. Tablet Processing Parameters (Continued).

\begin{tabular}{|c|c|c|}
\hline Unit Operation & Process Parameter & Physical Properties \\
\hline Tray Drying & $\begin{array}{ll}\text { - } & \text { Quantity of carts and trays per chamber } \\
\text { - } & \text { Quantity of product per tray } \\
\text { - } & \text { Drying time and temperature } \\
\text { - } & \text { Air flow } \\
\text { - } & \text { Inlet air dew point } \\
\text { - } & \text { Vacuum/microwave } \\
\text { - } & \text { Jacket temperature } \\
\text { - } & \text { Condenser temperature } \\
\text { - } & \text { Impeller speed } \\
\text { - } & \text { Vacuum strength } \\
\text { - } & \text { Microwave potency } \\
\text { - } & \text { Electric field } \\
\text { - } & \text { Energy supplied } \\
\text { - } & \text { Product temperature }\end{array}$ & $\begin{array}{l}\text { Moisture content } \\
\text { Residual solvents }\end{array}$ \\
\hline Roller Compaction & $\begin{array}{ll}\text { - } & \text { Roll speed } \\
\text { - } & \text { Gap setting } \\
\text { - } & \text { Roll pressure } \\
\text { - } & \text { Auger screw rate } \\
\text { - } & \text { Roller type } \\
\text { - } & \text { Mill speed } \\
\text { - } & \text { Mill type }\end{array}$ & $\begin{array}{l}\text { Appearance } \\
\text { Ribbon/particle size and shape } \\
\text { Ribbon density, strength, } \\
\text { and thickness } \\
\text { Solid form }\end{array}$ \\
\hline Tablet Compression & $\begin{array}{ll}\text { - } & \text { Compression speed and force } \\
\text { - } & \text { Pre-compression force } \\
\text { - } & \text { Feed frame type and speed } \\
\text { - } & \text { Hopper design, height, and vibration } \\
\text { - } & \text { Tablet weight and thickness } \\
\text { - } & \text { Depth of fill } \\
\text { - } & \text { Punch penetration depth }\end{array}$ & $\begin{array}{l}\text { Target weight } \\
\text { Weight uniformity } \\
\text { Content uniformity } \\
\text { Hardness } \\
\text { Thickness } \\
\text { Tablet porosity } \\
\text { Friability } \\
\text { Visual attributes } \\
\text { Moisture content } \\
\text { Weight of core tablets }\end{array}$ \\
\hline
\end{tabular}

\section{References}

1. Davidson, L.; Greblov, G. The Pharmaceutical Industry in the Global Economy; Indiana University Kelley School of Business: Bloomington, IN, USA, 2005.

2. Wening, K.; Breitkreutz, J. Oral drug delivery in personalized medicine: Unmet needs and novel approaches. Int. J. Pharm. 2011, 404, 1-9. [CrossRef] [PubMed]

3. Truffer, C.J.; Keehan, S.; Smith, S.; Cylus, J.; Sisko, A.; Poisal, J.A.; Lizonitz, J.; Clemens, M.K. Health spending projections through 2019: The recession's impact continues. Health Aff. 2010, 29, 522-529. [CrossRef] [PubMed] 
4. Kawabata, Y.; Wada, K.; Nakatani, M.; Yamada, S.; Onoue, S. Formulation design for poorly water-soluble drugs based on biopharmaceutics classification system: Basic approaches and practical applications. Int. J. Pharm. 2011, 420, 1-10. [CrossRef] [PubMed]

5. Wu, C.-Y.; Benet, L.Z. Predicting drug disposition via application of BCS: Transport/absorption/elimination interplay and development of a biopharmaceutics drug disposition classification system. Pharm. Res. 2005, 22, 11-23. [CrossRef] [PubMed]

6. Ku, M.S. Use of the biopharmaceutical classification system in early drug development. AAPS J. 2008, 10, $208-212$. [CrossRef]

7. Dahan, A.; Miller, J.M.; Amidon, G.L. Prediction of solubility and permeability class membership: Provisional BCS classification of the world's top oral drugs. AAPS J. 2009, 11, 740-746. [CrossRef]

8. Dressman, J.; Butler, J.; Hempenstall, J.; Reppas, C. The BCS: Where do we go from here? Pharm. Technol. Eur. 2001, 25, 68-77.

9. Hancock, B.C.; Carlson, G.T.; Ladipo, D.D.; Langdon, B.A.; Mullarney, M.P. Comparison of the mechanical properties of the crystalline and amorphous forms of a drug substance. Int. J. Pharm. 2002, 241, 73-85. [CrossRef]

10. Guinot, S.; Leveiller, F. The use of MTDSC to assess the amorphous phase content of a micronised drug substance. Int. J. Pharm. 1999, 192, 63-75. [CrossRef]

11. Pudipeddi, M.; Serajuddin, A.T. Trends in solubility of polymorphs. J. Pharm. Sci. 2005, 94, 929-939. [CrossRef]

12. Popović, M.R.; Popović, G.V.; Agbaba, D.D. The effects of anionic, cationic, and nonionic surfactants on acid-base equilibria of ACE inhibitors. J. Chem. Eng. Data 2013, 58, 2567-2573. [CrossRef]

13. Shao, Q.; Jiang, S. Molecular understanding and design of zwitterionic materials. Adv. Mater. 2015, $27,15-26$. [CrossRef] [PubMed]

14. Hari, A.C.; Paruchuri, R.A.; Sabatini, D.A.; Kibbey, T.C. Effects of $\mathrm{pH}$ and cationic and nonionic surfactants on the adsorption of pharmaceuticals to a natural aquifer material. Environ. Sci. Technol. 2005, 39, 2592-2598. [CrossRef] [PubMed]

15. Chaudhari, S.P.; Dugar, R. Application of surfactants in solid dispersion technology for improving solubility of poorly water soluble drugs. J. Drug Deliv. Sci. Technol. 2017, 41, 68-77. [CrossRef]

16. Chiappetta, D.A.; Carcaboso, Á.M.; Bregni, C.; Rubio, M.; Bramuglia, G.; Sosnik, A. Indinavir-loaded $\mathrm{pH}$-sensitive microparticles for taste masking: Toward extemporaneous pediatric anti-HIV/AIDS liquid formulations with improved patient compliance. AAPS PharmSciTech 2009, 10, 1-6. [CrossRef] [PubMed]

17. Nunn, T.; Williams, J. Formulation of medicines for children. Br. J. Clin. Pharmacol. 2005, 59, 674-676. [CrossRef] [PubMed]

18. Meyboom, R.H.; Lindquist, M.; Flygare, A.-K.; Biriell, C.; Edwards, I.R. The value of reporting therapeutic ineffectiveness as an adverse drug reaction. Drug Saf. 2000, 23, 95-99. [CrossRef] [PubMed]

19. Lawrence, X.Y. Pharmaceutical quality by design: Product and process development, understanding, and control. Pharm. Res. 2008, 25, 781-791.

20. Monforte, A.D.A.; Lepri, A.C.; Rezza, G.; Pezzotti, P.; Antinori, A.; Phillips, A.N.; Angarano, G.; Colangeli, V.; De Luca, A.; Ippolito, G. Insights into the reasons for discontinuation of the first highly active antiretroviral therapy (HAART) regimen in a cohort of antiretroviral naive patients. AIDS J. Acquir. Immune Defic. Syndr. 2000, 14, 499-507. [CrossRef]

21. Howard, R.; Avery, A.; Howard, P.; Partridge, M. Investigation into the reasons for preventable drug related admissions to a medical admissions unit: Observational study. BMJ Qual. Saf. 2003, 12, 280-285. [CrossRef]

22. Hänsel, A.; Bucher, H.C.; Nüesch, R.; Battegay, M. Reasons for discontinuation of first highly active antiretroviral therapy in a cohort of proteinase inhibitor-naive HIV-infected patients. AIDS J. Acquir. Immune Defic. Syndr. 2001, 26, 191-193. [CrossRef]

23. Peyriere, H.; Guillemin, V.; Lotthe, A.; Baillat, V.; Fabre, J.; Favier, C.; Atoui, N.; Hansel, S.; Hillaire-Buys, D.; Reynes, J. Reasons for early abacavir discontinuation in HIV-infected patients. Ann. Pharmacother. 2003, 37, 1392-1397. [CrossRef]

24. Verma, P.; Thakur, A.; Deshmukh, K.; Jha, A.; Verma, S. Routes of drug administration. Int. J. Pharm. Stud. Res. 2010, 1, 54-59.

25. Vila, A.; Sanchez, A.; Tobı, M.; Calvo, P.; Alonso, M. Design of biodegradable particles for protein delivery. J. Controll. Release 2002, 78, 15-24. [CrossRef] 
26. Olsson, P.; Bende, M.; Ohlin, P. The laser Doppler flowmeter for measuring microcirculation in human nasal mucosa. Acta Oto-Laryngol. 1985, 99, 133-139. [CrossRef]

27. Thorne, R.; Pronk, G.; Padmanabhan, V.; Frey Ii, W. Delivery of insulin-like growth factor-I to the rat brain and spinal cord along olfactory and trigeminal pathways following intranasal administration. Neuroscience 2004, 127, 481-496. [CrossRef]

28. Staniforth, J.N.; Sherwood, B.E.; Hunter, E.A. Pharmaceutical Formulations Having Improved Disintegration and/or Absorptivity. U.S. Patent 5,948,438, 7 September 1999.

29. Bodratti, A.M.; Alexandridis, P. Amphiphilic block copolymers in drug delivery: Advances in formulation structure and performance. Expert Opin. Drug Deliv. 2018, 15, 1085-1104. [CrossRef]

30. Bodratti, A.; Alexandridis, P. Formulation of Poloxamers for Drug Delivery. J. Funct. Biomater. $2018,9,11$. [CrossRef]

31. Yang, L.; Alexandridis, P. Physicochemical aspects of drug delivery and release from polymer-based colloids. Curr. Opin. Colloid Interface Sci. 2000, 5, 132-143. [CrossRef]

32. Agyilirah, G.A.; Banker, G.S. Polymers for enteric coating applications. Polym. Controll. Drug Deliv. 1991, 3, 39-66.

33. Klein, C.E.; Chiu, Y.-L.; Awni, W.; Zhu, T.; Heuser, R.S.; Doan, T.; Breitenbach, J.; Morris, J.B.; Brun, S.C.; Hanna, G.J. The tablet formulation of lopinavir/ritonavir provides similar bioavailability to the soft-gelatin capsule formulation with less pharmacokinetic variability and diminished food effect. J. Acquir. Immune Defic. Syndr. 2007, 44, 401-410. [CrossRef]

34. Wong, P.S.-L.; Edgren, D.E. Gastric Retaining Oral Liquid Dosage Form. U.S. Patent 6,635,281, 21 October 2003.

35. Lang, J.C. Ocular drug delivery conventional ocular formulations. Adv. Drug Deliv. Rev. 1995, 16, 39-43. [CrossRef]

36. Calvo, P.; Alonso, M.J.; Vila-Jato, J.L.; Robinson, J.R. Improved ocular bioavailability of indomethacin by novel ocular drug carriers. J. Pharm. Pharmacol. 1996, 48, 1147-1152. [CrossRef]

37. Sankar, V.; Durga, S.; Prasanth, K.; Nilani, P.; Geetha, G.; Ravich, V.; Vijayakumar, A.; Raghuraman, S. Formulation and stability evaluation of diclofenac sodium ophthalmic gels. Indian J. Pharm. Sci. 2005, 67, 473.

38. Mohamed, M.I. Optimization of chlorphenesin emulgel formulation. AAPS J. 2004, 6, 81-87. [CrossRef]

39. Wang, X.; Dellamary, L.; Fernandez, R.; Ye, Q.; LeBel, C.; Piu, F. Principles of inner ear sustained release following intratympanic administration. Laryngoscope 2011, 121, 385-391. [CrossRef]

40. Bergamini, M.V.; Mas, J.A.V.; Cabello, G.T.; Cabrera, A.L. Diclofenac and Tobramycin Formulations for Ophthalmic and Otic Topical Use. U.S. Patent 5,597,560, 28 January 1997.

41. Sweetana, S.; Akers, M.J. Solubility principles and practices for parenteral drug dosage form development. PDA J. Pharm. Sci. Technol. 1996, 50, 330-342.

42. Jain, J.; Fernandes, C.; Patravale, V.J.A.P. Formulation development of parenteral phospholipid-based microemulsion of etoposide. AAPS PharmSciTech 2010, 11, 826-831. [CrossRef]

43. Lee, Y.-C.; Zocharski, P.D.; Samas, B. An intravenous formulation decision tree for discovery compound formulation development. Int. J. Pharm. 2003, 253, 111-119. [CrossRef]

44. Dobrozsi, D.J.; Jerry, W.H.I.; Lindman, B.O.; Ivanova, R.H.; Alexandridis, P. Pourable Liquid Vehicles. U.S. Patent 6,503,955, 7 January 2003.

45. Miyake, M.; Kamada, N.; Oka, Y.; Mukai, T.; Minami, T.; Toguchi, H.; Odomi, M.; Ogawara, K.-i.; Higaki, K.; Kimura, T. Development of suppository formulation safely improving rectal absorption of rebamipide, a poorly absorbable drug, by utilizing sodium laurate and taurine. J. Controll. Release 2004, 99, 63-71. [CrossRef]

46. Setnikar, I.; Fantelli, S. Liquefaction time of rectal suppositories. J. Pharm. Sci. 1962, 51, 566-571. [CrossRef]

47. Harrison, T.S.; Cokeley, B.J. Suppository Applicator. U.S. Patent 5,788,664, 4 August 1998.

48. Sperti, G.S. Suppository. U.S. Patent 3,415,249, 10 December 1968.

49. Gowthamarajan, K.; Kulkarni, T.G.; Venkateswaran, G.; Samanta, M.; Suresh, B. Formulation and dissolution properties of meloxicam solid dispersion incorporated suppositories. Indian J. Pharm. Sci. 2002, 64, 525.

50. Ghodake, P.P.; Karande, K.M.; Osmani, R.A.; Bhosale, R.R.; Harkare, B.R.; Kale, B.B. Mouth dissolving films: Innovative vehicle for oral drug delivery. Int. J. Pharma Res. Rev. 2013, 2, 41-47.

51. Richey, R.H.; Hughes, C.; Craig, J.V.; Shah, U.U.; Ford, J.L.; Barker, C.E.; Peak, M.; Nunn, A.J.; Turner, M.A. A systematic review of the use of dosage form manipulation to obtain required doses to inform use of manipulation in paediatric practice. Int. J. Pharm. 2017, 518, 155-166. [CrossRef] 
52. Cox, L.S.; Linnemann, D.L.; Nolte, H.; Weldon, D.; Finegold, I.; Nelson, H.S. Sublingual immunotherapy: A comprehensive review. J. Allergy Clin. Immunol. 2006, 117, 1021-1035. [CrossRef]

53. Singh, S.K.; Sameer, A.A. Development and characterization of sublingual tablet of Lisinopril. Asian Pac. J. Trop. Biomed. 2012, 2, S1711-S1719. [CrossRef]

54. Bhyan, B.; Jangra, S.; Kaur, M.; Singh, H. Orally fast dissolving films: Innovations in formulation and technology. Int. J. Pharm. Sci. Rev. Res. 2011, 9, 9-15.

55. Wehling, F.; Schuehle, S.; Madamala, N. Pediatric Effervescent Dosage Form. U.S. Patent 5,223,264, 29 June 1993.

56. Prausnitz, M.R.; Langer, R. Transdermal drug delivery. Nat. Biotechnol. 2008, 26, 1261. [CrossRef]

57. Benson, H.A. Transdermal drug delivery: Penetration enhancement techniques. Curr. Drug Deliv. 2005, 2, $23-33$. [CrossRef]

58. Prausnitz, M.R.; Mitragotri, S.; Langer, R. Current status and future potential of transdermal drug delivery. Nat. Rev. Drug Discov. 2004, 3, 115-124. [CrossRef]

59. Donnelly, L.; Curran, R.M.; Tregoning, J.S.; McKay, P.F.; Cole, T.; Morrow, R.J.; Kett, V.L.; Andrews, G.P.; Woolfson, A.D.; Malcolm, R.K. Intravaginal immunization using the recombinant HIV-1 clade-C trimeric envelope glycoprotein CN54gp140 formulated within lyophilized solid dosage forms. Vaccine 2011, 29, 4512-4520. [CrossRef]

60. Sastry, S.V.; Nyshadham, J.R.; Fix, J.A. Recent technological advances in oral drug delivery-A review. Pharm. Sci. Technol. Today 2000, 3, 138-145. [CrossRef]

61. Charman, W.N.; Porter, C.J.; Mithani, S.; Dressman, J.B. Physicochemical and physiological mechanisms for the effects of food on drug absorption: The role of lipids and pH. J. Pharm. Sci. 1997, 86, 269-282. [CrossRef]

62. Levy, G. Comparison of dissolution and absorption rates of different commercial aspirin tablets. J. Pharm. Sci. 1961, 50, 388-392. [CrossRef]

63. Greenblatt, D.J.; Smith, T.W.; Koch-Weser, J. Bioavailability of drugs: The digoxin dilemma. Clin. Pharmacokinet. 1976, 1, 36-51. [CrossRef]

64. Ford, J.L.; Rubinstein, M.H.; McCaul, F.; Hogan, J.E.; Edgar, P.J. Importance of drug type, tablet shape and added diluents on drug release kinetics from hydroxypropylmethylcellulose matrix tablets. Int. J. Pharm. 1987, 40, 223-234. [CrossRef]

65. Wan, X.; Woods, A.T.; Salgado-Montejo, A.; Velasco, C.; Spence, C. Assessing the expectations associated with pharmaceutical pill colour and shape. Food Qual. Prefer. 2015, 45, 171-182. [CrossRef]

66. Rähse, W.; Hoffmann, S. Product Design-The Interaction between Chemistry, Technology and Marketing to Meet Customer Needs. Chem. Eng. Technol. 2003, 26, 931-940. [CrossRef]

67. Aagaard, L.; Rossi, J.J. RNAi therapeutics: Principles, prospects and challenges. Adv. Drug Deliv. Rev. 2007, 59, 75-86. [CrossRef]

68. Ramkissoon-Ganorkar, C.; Liu, F.; Baudyš, M.; Kim, S.W. Modulating insulin-release profile from pH/thermosensitive polymeric beads through polymer molecular weight. J. Controll. Release 1999, 59, 287-298. [CrossRef]

69. Thanoo, B.; Sunny, M.; Jayakrishnan, A. Oral Sustained-release Drug Delivery Systems using Polycarbonate Microspheres Capable of Floating on the Gastric Fluid. J. Pharm. Pharmacol. 1993, 45, 21-24. [CrossRef]

70. Lehmann, K.; Gerhard, A.; Horrichs-Haermeyer, G.; Grond, S.; Zech, D. Postoperative patient-controlled analgesia with sufentanil: Analgesic efficacy and minimum effective concentrations. Acta Anaesthesiol. Scand. 1991, 35, 221-226. [CrossRef]

71. Goldstein, A.; Aronow, L.; Kalman, S.M. Principles of Drug Action; the Basis of Pharmacology; Hoeber Medical Division, Harper \& Row: New York, NY, USA, 1968.

72. Huang, L.-F.; Tong, W.-Q.T. Impact of solid state properties on developability assessment of drug candidates. Adv. Drug Deliv. Rev. 2004, 56, 321-334. [CrossRef]

73. Zhang, G.G.; Law, D.; Schmitt, E.A.; Qiu, Y. Phase transformation considerations during process development and manufacture of solid oral dosage forms. Adv. Drug Deliv. Rev. 2004, 56, 371-390. [CrossRef]

74. Dunitz, J.D.; Bernstein, J. Disappearing polymorphs. Acc. Chem. Res. 1995, 28, 193-200. [CrossRef]

75. Warne, N.W. Development of high concentration protein biopharmaceuticals: The use of platform approaches in formulation development. Eur. J. Pharm. Biopharm. 2011, 78, 208-212. [CrossRef]

76. Davis, J.M. Comparative doses and costs of antipsychotic medication. Arch. Gen. Psychiatry 1976, 33, 858-861. [CrossRef]

77. Van Santen, E.; Barends, D.; Frijlink, H. Breaking of scored tablets: A review. Eur. J. Pharm. Biopharm. 2002, 53, 139-145. [CrossRef] 
78. Rodenhuis, N.; De Smet, P.A.; Barends, D.M. The rationale of scored tablets as dosage form. Eur. J. Pharm. Sci. 2004, 21, 305-308. [CrossRef]

79. Verrue, C.; Mehuys, E.; Boussery, K.; Remon, J.P.; Petrovic, M. Tablet-splitting: A common yet not so innocent practice. J. Adv. Nurs. 2011, 67, 26-32. [CrossRef]

80. Habib, W.A.; Alanizi, A.S.; Abdelhamid, M.M.; Alanizi, F.K. Accuracy of tablet splitting: Comparison study between hand splitting and tablet cutter. Saudi Pharm. J. 2014, 22, 454-459. [CrossRef]

81. Quinzler, R.; Szecsenyi, J.; Haefeli, W. Tablet splitting: Patients and physicians need better support. Eur. J. Clin. Pharmacol. 2007, 63, 1203-1204. [CrossRef]

82. Teng, J.; Song, C.K.; Williams, R.L.; Polli, J.E. Lack of medication dose uniformity in commonly split tablets. J. Am. Pharm. Assoc. 2002, 42, 195-199. [CrossRef]

83. Mc Gillicuddy, A.; Kelly, M.; Crean, A.M.; Sahm, L.J. The knowledge, attitudes and beliefs of patients and their healthcare professionals around oral dosage form modification: A systematic review of the qualitative literature. Res. Soc. Adm. Pharm. 2017, 13, 717-726. [CrossRef]

84. Freeman, M.K.; White, W.; Iranikhah, M. Tablet Splitting: A Review of Weight and Content Uniformity Part 1 of a 2-Part Series. Consult. Pharm. J. Am. Soc. Consult. Pharm. 2012, 27, 341-352. [CrossRef]

85. Debotton, N.; Dahan, A. Applications of polymers as pharmaceutical excipients in solid oral dosage forms. Med. Res. Rev. 2017, 37, 52-97. [CrossRef]

86. Leslie, S.T. Slow Release Pharmaceutical Compositions. U.S. Patent 3,965,256, 22 June 1976.

87. Krause, G.M.; Ninger, F.C. Tablet Structure. U.S. Patent 3,336,200, 15 August 1967.

88. Lau, E.T.; Steadman, K.J.; Cichero, J.A.; Nissen, L.M. Dosage form modification and oral drug delivery in older people. Adv. Drug Deliv. Rev. 2018, 135, 75-84. [CrossRef]

89. Forough, A.S.; Lau, E.T.; Steadman, K.J.; Cichero, J.A.; Kyle, G.J.; Santos, J.M.S.; Nissen, L.M. A spoonful of sugar helps the medicine go down? A review of strategies for making pills easier to swallow. Patient Prefer. Adherence 2018, 12, 1337-1346. [CrossRef]

90. Elliott, I.; Mayxay, M.; Yeuichaixong, S.; Lee, S.J.; Newton, P.N. The practice and clinical implications of tablet splitting in international health. Trop. Med. Int. Health 2014, 19, 754-760. [CrossRef]

91. Helmy, S.A. Tablet splitting: Is it worthwhile? Analysis of drug content and weight uniformity for half tablets of 16 commonly used medications in the outpatient setting. J. Manag. Care Spec. Pharm. 2015, 21, 76-88. [CrossRef]

92. Harrison, M.; Busto, U.; Naranjo, C.; Kaplan, H.; Sellers, E. Diazepam tapering in detoxification for high-dose benzodiazepine abuse. Clin. Pharmacol. Ther. 1984, 36, 527-533. [CrossRef]

93. Cathcart, R.F. Vitamin C, titrating to bowel tolerance, anascorbemia, and acute induced scurvy. Med. Hypotheses 1981, 7, 1359-1376. [CrossRef]

94. Breitkreutz, J.; Boos, J. Paediatric and geriatric drug delivery. Expert Opin. Drug Deliv. 2007, 4, 37-45. [CrossRef]

95. Yusuf, S.; Peto, R.; Lewis, J.; Collins, R.; Sleight, P. Beta blockade during and after myocardial infarction: An overview of the randomized trials. Prog. Cardiovasc. Dis 1985, 27, 335-371. [CrossRef]

96. Yeager, R.A.; Moneta, G.L.; Edwards, J.M.; Taylor, L.M.; McConnell, D.B.; Porter, J.M. Reducing Perioperative Myocardial Infarction Following Vascular Surgery: The Potential Role of $\beta$-Blockade. Arch. Surg. 1995, 130, 869-873. [CrossRef]

97. Rydén, L.; Standl, E.; Bartnik, M.; Van den Berghe, G.; Betteridge, J.; De Boer, M.-J.; Cosentino, F.; Jönsson, B.; Laakso, M.; Malmberg, K. Guidelines on diabetes, pre-diabetes, and cardiovascular diseases: Executive summary: The Task Force on Diabetes and Cardiovascular Diseases of the European Society of Cardiology (ESC) and of the European Association for the Study of Diabetes (EASD). Eur. Heart J. 2007, 28, 88-136.

98. Stafford, R.S.; Radley, D.C. The potential of pill splitting to achieve cost savings. Am. J. Manag. Care 2002, 8, 706-712.

99. Cobby, J.; Mayersohn, M.; Walker, G.C. Influence of shape factors on kinetics of drug release from matrix tablets I: Theoretical. J. Pharm. Sci. 1974, 63, 725-732. [CrossRef]

100. Gupta, A.; Hunt, R.L.; Khan, M.A. Influence of tablet characteristics on weight variability and weight loss in split tablets. Am. J. Health-Syst. Pharm. 2008, 65, 2326-2328. [CrossRef]

101. Didier, A.; Malling, H.-J.; Worm, M.; Horak, F.; Jäger, S.; Montagut, A.; André, C.; de Beaumont, O.; Melac, M. Optimal dose, efficacy, and safety of once-daily sublingual immunotherapy with a 5-grass pollen tablet for seasonal allergic rhinitis. J. Allergy Clin. Immunol. 2007, 120, 1338-1345. [CrossRef]

102. Katikaneni, P.R.; Upadrashta, S.M.; Neau, S.H.; Mitra, A.K. Ethylcellulose matrix controlled release tablets of a water-soluble drug. Int. J. Pharm. 1995, 123, 119-125. [CrossRef] 
103. Bodmeier, R. Tableting of coated pellets. Eur. J. Pharm. Biopharm. 1997, 43, 1-8. [CrossRef]

104. Seitz, J.A.; Flessland, G.M. Evaluation of the physical properties of compressed tablets I: Tablet hardness and friability. J. Pharm. Sci. 1965, 54, 1353-1357. [CrossRef]

105. Muti, H.; Othman, S. Effects of binders and moisture content on the disintegration, hardness and friability of paracetamol and orphenadrine citrate tablets. Drug Dev. Ind. Pharm. 1989, 15, 2017-2035. [CrossRef]

106. Lakshman, J.P.; Kowalski, J.; Vasanthavada, M.; Tong, W.Q.; Joshi, Y.M.; Serajuddin, A.T. Application of melt granulation technology to enhance tabletting properties of poorly compactible high-dose drugs. J. Pharm. Sci. 2011, 100, 1553-1565. [CrossRef]

107. Cook, T.J.; Edwards, S.; Gyemah, C.; Shah, M.; Shah, I.; Fox, T. Variability in tablet fragment weights when splitting unscored cyclobenzaprine $10 \mathrm{mg}$ tablets. J. Am. Pharm. Assoc. 2004, 44, 583-586. [CrossRef]

108. Zaid, A.N.; Rowa'J, A.-R.; Ghoush, A.A.; Qaddumi, A.; Zaaror, Y.A. Weight and content uniformity of lorazepam half-tablets: A study of correlation of a low drug content product. Saudi Pharm. J. 2013, 21, 71-75. [CrossRef]

109. Bachynsky, J.; Wiens, C.; Melnychuk, K. The practice of splitting tablets. Pharmacoeconomics 2002, 20, 339-346. [CrossRef]

110. Kolodny, A.; Courtwright, D.T.; Hwang, C.S.; Kreiner, P.; Eadie, J.L.; Clark, T.W.; Alexander, G.C. The prescription opioid and heroin crisis: A public health approach to an epidemic of addiction. Ann. Rev. Public Health 2015, 36, 559-574. [CrossRef]

111. Yarborough, B.J.H.; Stumbo, S.P.; Janoff, S.L.; Yarborough, M.T.; McCarty, D.; Chilcoat, H.D.; Coplan, P.M.; Green, C.A. Understanding opioid overdose characteristics involving prescription and illicit opioids: A mixed methods analysis. Drug Alcohol Depend. 2016, 167, 49-56. [CrossRef]

112. Alexander, L.; Mannion, R.O.; Weingarten, B.; Fanelli, R.J.; Stiles, G.L. Development and impact of prescription opioid abuse deterrent formulation technologies. Drug Alcohol Depend. 2014, 138, 1-6. [CrossRef]

113. Koob, G.F.; Pettit, H.O.; Ettenberg, A.; Bloom, F.E. Effects of opiate antagonists and their quaternary derivatives on heroin self-administration in the rat. J. Pharmacol. Exp. Ther. 1984, 229, 481-486.

114. Vosburg, S.K.; Jones, J.D.; Manubay, J.M.; Ashworth, J.B.; Benedek, I.H.; Comer, S.D. Assessment of a formulation designed to be crush-resistant in prescription opioid abusers. Drug Alcohol Depend. 2012, 126, 206-215. [CrossRef]

115. Schneider, J.P.; Matthews, M.; Jamison, R.N. Abuse-deterrent and tamper-resistant opioid formulations. CNS Drugs 2010, 24, 805-810. [CrossRef]

116. Stegemann, S.; Ecker, F.; Maio, M.; Kraahs, P.; Wohlfart, R.; Breitkreutz, J.; Zimmer, A.; Bar-Shalom, D.; Hettrich, P.; Broegmann, B. Geriatric drug therapy: Neglecting the inevitable majority. Ageing Res. Rev. 2010, 9, 384-398. [CrossRef]

117. Rodenhuis, N.; Barends, D.; de Smet, P. Patient experiences with the performance of tablet score lines needed for dosing. Pharm. World Sci. 2003, 25, 173-176. [CrossRef]

118. Van der Steen, K.C.; Frijlink, H.W.; Schipper, C.M.A.; Barends, D.M. Prediction of the ease of subdivision of scored tablets from their physical parameters. AAPS Pharmscitech 2010, 11, 126-132. [CrossRef]

119. Van Riet-Nales, D.A.; Doeve, M.E.; Nicia, A.E.; Teerenstra, S.; Notenboom, K.; Hekster, Y.A.; van den Bemt, B.J. The accuracy, precision and sustainability of different techniques for tablet subdivision: Breaking by hand and the use of tablet splitters or a kitchen knife. Int. J. Pharm. 2014, 466, 44-51. [CrossRef]

120. Somogyi, O.; Meskó, A.; Csorba, L.; Szabó, P.; Zelkó, R. Pharmaceutical counselling about different types of tablet-splitting methods based on the results of weighing tests and mechanical development of splitting devices. Eur. J. Pharm. Sci. 2017, 106, 262-273. [CrossRef]

121. Fahelelbom, K.; Al-Tabakha, M.; Eissa, N.; Javadi, J. Evaluation of Certain Pharmaceutical Quality Attributes of Lisinopril Split Tablets. Sci. Pharm. 2016, 84, 646-653. [CrossRef]

122. Van Reuler, A.V.; van Diemen, J.J.; Harmsze, A.M.; Fuijkschot, W.W.; Thijs, A. Subdivision of aspirin tablets? Use your hands: A study on aspirin tablet subdivision using four different methods. J. Pharm. Pract. Res. Soc. Adm. Pharm. 2018, 48, 44-48. [CrossRef]

123. Eserian, J.K.; Lombardo, M. Tablet subdivision: Far beyond the splitting technique. Int. J. Pharm. 2014, 476, 77. [CrossRef]

124. Van Vooren, L.; De Spiegeleer, B.; Thonissen, T.; Joye, P.; Van Durme, J.; Slegers, G. Statistical analysis of tablet breakability methods. Int. J. Pharm. Pharm. Sci. 2002, 5, 190-198.

125. Zhang, Y.; Johnson, K.C.J. Effect of drug particle size on content uniformity of low-dose solid dosage forms. Int. J. Pharm. 1997, 154, 179-183. [CrossRef] 
126. Abu-Geras, D.; Hadziomerovic, D.; Leau, A.; Khan, R.N.; Gudka, S.; Locher, C.; Razaghikashani, M.; Lim, L.Y. Accuracy of tablet splitting and liquid measurements: An examination of who, what and how. J. Pharm. Pharmacol. 2017, 69, 603-612. [CrossRef]

127. Temer, A.C.; Teixeira, M.T.; Sa-Barreto, L.L.; Gratieri, T.; Gelfuso, G.M.; Silva, I.C.; Taveira, S.F.; Marreto, R.N.; Cunha-Filho, M. Subdivision of Tablets Containing Modified Delivery Technology: The Case of Orally Disintegrating Tablets. J. Pharm. Innov. 2018, 13, 261-269. [CrossRef]

128. Chou, C.-Y.; Hsu, C.-C.; Chiang, S.-C.; Ho, C.-C.; Chou, C.-L.; Wu, M.-S.; Chang, Y.-L.; Tsai, H.-Y.; Chen, T.-J.; Chou, Y.-C. Association between physician specialty and risk of prescribing inappropriate pill splitting. PLoS ONE 2013, 8, e70113. [CrossRef]

129. Thong, M.Y.; Manrique, Y.J.; Steadman, K.J. Drug loss while crushing tablets: Comparison of 24 tablet crushing devices. PLoS ONE 2018, 13, e0193683. [CrossRef]

130. Trivedi, M.R.; Patel, H.H.; Dave, R.H. A Review on Tablet Scoring: Background, History and Current Regulatory Considerations. J. Pharm. Res. Int. 2017, 20, 1-7. [CrossRef]

131. Harbir, K. Processing technologies for pharmaceutical tablets: A review. Int. Res. J. Pharm. 2012, 3, $20-23$.

132. Nayak, A.K.; Manna, K. Current developments in orally disintegrating tablet technology. J. Pharm. Educ. Res. Soc. Adm. Pharm. 2011, 2, 21-34.

133. Spiegeleer, B.D.; Hoorebeke, L.V.; Spiegeleer, A.D.; Castelein, P.; Bortel, L.V. The paradox of scored tablets: A cost-saving risk. Die Pharm. Int. J. Pharm. Sci. 2009, 64, 550-552.

134. Biron, C.; Licznar, P.; Hansel, S.; Schved, J. Oral anticoagulant drugs: Do not cut tablets in quarters. Thromb. Haemost. 1999, 82, 1201.

135. Glickman, S.W.; Anstrom, K.J.; Lin, L.; Chandra, A.; Laskowitz, D.T.; Woods, C.W.; Freeman, D.H.; Kraft, M.; Beskow, L.M.; Weinfurt, K.P. Challenges in enrollment of minority, pediatric, and geriatric patients in emergency and acute care clinical research. Ann. Emerg. Med. 2008, 51, 775-780. [CrossRef]

136. Pahwa, R.; Piplani, M.; Sharma, P.C.; Kaushik, D.; Nanda, S. Orally disintegrating tablets-Friendly to pediatrics and geriatrics. Arch. Appl. Sci. Res. 2010, 2, 35-48.

137. Peek, B.T.; Al-Achi, A.; Coombs, S. Accuracy of tablet splitting by elderly patients. J. Am. Med. Assoc. 2002, 288, 451-452. [CrossRef]

138. Gerber, J.E.; Cawthon, B. Overdose and death with olanzapine: Two case reports. Am. J. Forensic Med. Pathol. 2000, 21, 249-251. [CrossRef]

139. Marques, M.R.; Brown, W. Updates on USP activities related to dissolution, disintegration, and drug release. Dissolution Technol. 2013, 20, 54-56. [CrossRef]

140. Allemann, S.S.; Bornand, D.; Hug, B.; Hersberger, K.E.; Arnet, I. Issues around the prescription of half tablets in Northern Switzerland: The irrational case of quetiapine. BioMed Res. Int. 2015, 2015, 602021. [CrossRef]

141. Strickley, R.G.; Iwata, Q.; Wu, S.; Dahl, T.C. Pediatric drugs-A review of commercially available oral formulations. J. Pharm. Sci. 2008, 97, 1731-1774. [CrossRef]

142. Nagar, P.; Singh, K.; Chauhan, I.; Verma, M.; Yasir, M.; Khan, A.; Sharma, R.; Gupta, N. Orally disintegrating tablets: Formulation, preparation techniques and evaluation. J. Appl. Pharm. Sci. 2011, 1, 35-45.

143. Ghebre-Sellassie, I.; Gordon, R.H.; Harris, M.R.; Nesbitt, R.U., Jr. Process for Treating Dosage Forms. U.S. Patent 4,600,645, 15 June 1986.

144. Breitenbach, J.; Kleinke, A.; Kothrade, S.; Rosenberg, J. Process for Producing Solid Dosage Forms by Extrusion. U.S. Patent 6,221,368, 24 April 2001.

145. Bushra, R.; Shoaib, M.H.; Aslam, N.; Hashmat, D.; Rehman, M. Formulation Development and Optimization of Ibuprofen Tablets by Direct Compression Method. J. Pharm. Sci. 2008, 21, 113-120.

146. Nusheh, M.; Yoozbashizadeh, H.; Askari, M.; Kuwata, N.; Kawamura, J.; Kano, J.; Saito, F.; Kobatake, H.; Fukuyama, H. Effect of mechanical milling on carbothermic reduction of magnesia. ISIJ Int. 2010, 50, 668-672. [CrossRef]

147. Olsen, J.L.; Rippie, E.G.J. Segregation kinetics of particulate solids systems I. Influence of particle size and particle size distribution. J. Pharm. Sci. 1964, 53, 147-150. [CrossRef]

148. Suresh, P.; Sreedhar, I.; Vaidhiswaran, R.; Venugopal, A. A comprehensive review on process and engineering aspects of pharmaceutical wet granulation. Chem. Eng. J. 2017, 328, 785-815. [CrossRef]

149. Pereira, G.R.S.; Taveira, S.F.; Cunha-Filho, M.; Marreto, R.N. The Effects of Fillers and Binders on the Accuracy of Tablet Subdivision. AAPS PharmSciTech 2018, 19, 2929-2933. [CrossRef] 
150. Faure, A.; York, P.; Rowe, R. Process control and scale-up of pharmaceutical wet granulation processes: A review. Eur. J. Pharm. Biopharm. 2001, 52, 269-277. [CrossRef]

151. Tan, H.; Salman, A.; Hounslow, M. Kinetics of fluidised bed melt granulation I: The effect of process variables. Chem. Eng. Sci. 2006, 61, 1585-1601. [CrossRef]

152. Rajniak, P.; Mancinelli, C.; Chern, R.; Stepanek, F.; Farber, L.; Hill, B. Experimental study of wet granulation in fluidized bed: Impact of the binder properties on the granule morphology. Int. J. Pharm. 2007, 334, 92-102. [CrossRef]

153. Daniher, D.; Briens, L.; Tallevi, A. End-point detection in high-shear granulation using sound and vibration signal analysis. Powder Technol. 2008, 181, 130-136. [CrossRef]

154. McMillan, J.; Briens, C.; Berruti, F.; Chan, E. High velocity attrition nozzles in fluidized beds. Powder Technol. 2007, 175, 133-141. [CrossRef]

155. Frake, P.; Greenhalgh, D.; Grierson, S.; Hempenstall, J.; Rudd, D. Process control and end-point determination of a fluid bed granulation by application of near infra-red spectroscopy. Int. J. Pharm. 1997, 151, 75-80. [CrossRef]

156. Dixit, R.; Puthli, S. Fluidization technologies: Aerodynamic principles and process engineering. J. Pharm. Sci. 2009, 98, 3933-3960. [CrossRef]

157. Osborne, J.D.; Sochon, R.P.; Cartwright, J.J.; Doughty, D.G.; Hounslow, M.J.; Salman, A.D. Binder addition methods and binder distribution in high shear and fluidised bed granulation. Chem. Eng. Res. Des. 2011, 89, 553-559. [CrossRef]

158. Kleinebudde, P. Roll compaction/dry granulation: Pharmaceutical applications. Eur. J. Pharm. Biopharm. 2004, 58, 317-326. [CrossRef]

159. Ito, A.; Dobashi, Y.; Sugihara, M. The relationship between dividing properties of scored tablets and dynamic characteristics of various mixed powders. Chem. Pharm. Bull. 1993, 41, 590-594. [CrossRef]

160. Jivraj, M.; Martini, L.G.; Thomson, C.M. An overview of the different excipients useful for the direct compression of tablets. Pharm. Sci. Technol. Today 2000, 3, 58-63. [CrossRef]

161. Sugimori, K.; Mori, S.; Kawashima, Y. Characterization of die wall pressure to predict capping of flat-or convex-faced drug tablets of various sizes. Powder Technol. 1989, 58, 259-264. [CrossRef]

162. Patel, S.; Kaushal, A.M.; Bansal, A.K. Compression physics in the formulation development of tablets. Crit. Rev. Ther. Drug Carr. Syst. 2006, 23, 15-19. [CrossRef]

163. De Spiegeleer, B.; Van Vooren, L.; Thonissen, T.; Joye, P. Mass uniformity: Influence of operational compression conditions on breakability of scored tablets as part of manufacturing robustness evaluation. J. Food Drug Anal. 2005, 13, 22-29.

164. Katare, Y.K.; Panda, A.K. Influences of excipients on in vitro release and in vivo performance of tetanus toxoid loaded polymer particles. Eur. J. Pharm. Sci. 2006, 28, 179-188. [CrossRef]

165. David, S.; Augsburger, L. Plastic flow during compression of directly compressible fillers and its effect on tablet strength. J. Pharm. Sci. 1977, 66, 155-159. [CrossRef]

166. Morkhade, D.M. Comparative impact of different binder addition methods, binders and diluents on resulting granule and tablet attributes via high shear wet granulation. Powder Technol. 2017, 320, 114-124. [CrossRef]

167. Castello, R.A.; Mattocks, A.M. Discoloration of tablets containing amines and lactose. J. Pharm. Sci. 1962, 51, $106-108$. [CrossRef]

168. Teixeira, M.T.; Sá-Barreto, L.C.; Gratieri, T.; Gelfuso, G.M.; Silva, I.C.; Cunha-Filho, M.S. Key technical aspects influencing the accuracy of tablet subdivision. AAPS PharmSciTech 2017, 18, 1393-1401. [CrossRef]

169. Roberts, R.; Rowe, R. Brittle/ductile behaviour in pharmaceutical materials used in tabletting. Int. J. Pharm. 1987, 36, 205-209. [CrossRef]

170. Vromans, H.; De Boer, A.; Bolhuis, G.; Lerk, C.; Kussendrager, K.; Bosch, H. Studies on tableting properties of lactose. Pharm. Weekbl. 1985, 7, 186-193. [CrossRef]

171. Bolhuis, G.; Zuurman, K. Tableting properties of experimental and commercially available lactose granulations for direct compression. Drug Dev. Ind. Pharm. 1995, 21, 2057-2071. [CrossRef]

172. Tu, W.-D.; Hsiau, S.-S.; Ingram, A.; Seville, J. The effect of powder size on induction behaviour and binder distribution during high shear melt agglomeration of calcium carbonate. Powder Technol. 2008, 184, $298-312$. [CrossRef]

173. Arndt, O.-R.; Kleinebudde, P. Towards a better understanding of dry binder functionality. Int. J. Pharm. 2018, 552, 258-264. [CrossRef] 
174. Zhang, Y.; Law, Y.; Chakrabarti, S. Physical properties and compact analysis of commonly used direct compression binders. AAPS PharmSciTech 2003, 4, 489-499. [CrossRef]

175. Joneja, S.; Harcum, W.; Skinner, G.; Barnum, P.; Guo, J.-H. Investigating the fundamental effects of binders on pharmaceutical tablet performance. Drug Dev. Ind. Pharm. 1999, 25, 1129-1135. [CrossRef]

176. Du, T. Binders in pharmaceutical granulation. In Handbook of Pharmaceutical Granulation Technology, 3rd ed.; CRC Press: Boca Raton, FL, USA, 2016; pp. 93-112.

177. Krycer, I.; Pope, D.G.; Hersey, J.A. An evaluation of tablet binding agents part I. Solution binders. Powder Technol. 1983, 34, 39-51. [CrossRef]

178. Shah, A.; Mlodozeniec, A. Mechanism of surface lubrication: Influence of duration of lubricant-excipient mixing on processing characteristics of powders properties of compressed tablets. J. Pharm. Sci. 1977, 66, 1377-1382. [CrossRef]

179. Paul, S.; Sun, C.C. Systematic evaluation of common lubricants for optimal use in tablet formulation. Eur. J. Pharm. Sci. 2018, 117, 118-127. [CrossRef]

180. Wang, J.; Wen, H.; Desai, D.J. Lubrication in tablet formulations. Eur. J. Pharm. Biopharm. 2010, 75, 1-15. [CrossRef]

181. Rizk, S.; Guyot, J.; Duru, C.; Gaudy, D. Influence of lubricant properties on compression behaviour and drug dissolution rate of scleroglucan hydrophilic matrix. Int. J. Pharm. 1995, 126, 57-63. [CrossRef]

182. Dürig, T.; Fassihi, R. Mechanistic evaluation of binary effects of magnesium stearate and talc as dissolution retardants at 85\% drug loading in an experimental extended-release formulation. J. Pharm. Sci. 1997, 86, 1092-1098. [CrossRef]

183. Chattoraj, S.; Sun, C.C. Crystal and particle engineering strategies for improving powder compression and flow properties to enable continuous tablet manufacturing by direct compression. J. Pharm. Sci. 2018, 107, 968-974. [CrossRef]

184. Jonat, S.; Hasenzahl, S.; Gray, A.; Schmidt, P.C. Mechanism of glidants: Investigation of the effect of different colloidal silicon dioxide types on powder flow by atomic force and scanning electron microscopy. J. Pharm. Sci. 2004, 93, 2635-2644. [CrossRef]

185. Wojcik-Pastuszka, D.; Juszkiewicz, K.; Özhan, G.; Musiał, W. Influence of Tablet Splitting on Dissolution of Tablets with Naproxen Sodium. Dissolution Technol. 2018, 25, 16-23. [CrossRef]

186. Pandey, P.; Levins, C.; Pafiakis, S.; Zacour, B.; Bindra, D.S.; Trinh, J.; Buckley, D.; Gour, S.; Sharif, S.; Stamato, H. Enhancing tablet disintegration characteristics of a highly water-soluble high-drug-loading formulation by granulation process. Pharm. Dev. Technol. 2018, 23, 587-595. [CrossRef]

187. Van Kamp, H.; Bolhuis, G.; Lerk, C. Improvement by super disintegrants of the properties of tablets containing lactose, prepared by wet granulation. Pharm. Weekbl. 1983, 5, 165-171. [CrossRef]

188. Alebiowu, G.; Itiola, O.A. Effects of starches on the mechanical properties of paracetamol tablet formulations. II. Sorghum and plantain starches as disintegrants. Acta Pharm. 2003, 53, 313-320.

189. Mohanachandran, P.; Sindhumol, P.; Kiran, T. Superdisintegrants: An overview. Int. J. Pharm. Sci. Rev. Res. 2011, 6, 105-109.

190. Rohrs, B.R.; Amidon, G.E.; Meury, R.H.; Secreast, P.J.; King, H.M.; Skoug, C.J. Particle size limits to meet USP content uniformity criteria for tablets and capsules. J. Pharm. Sci. 2006, 95, 1049-1059. [CrossRef]

191. Zhao, N.; Zidan, A.; Tawakkul, M.; Sayeed, V.A.; Khan, M. Tablet splitting: Product quality assessment of metoprolol succinate extended release tablets. Int. J. Pharm. 2010, 401, 25-31. [CrossRef]

192. Duman, E.; Yuksel, N.; Olin, B.; Sakr, A. Effect of scoring design on the uniformity of extended release matrix tablet halves. Pharm. Ind. 2000, 62, 547-550.

193. Saha, S.; Shahiwala, A. Multifunctional coprocessed excipients for improved tabletting performance. Expert Opin. Drug Deliv. 2009, 6, 197-208. [CrossRef]

194. Navarro, R.P. Tablet splitting: Much ado about nothing? J. Manag. Care Pharm. 2009, 15, 272-274. [CrossRef]

195. Shah, R.B.; Collier, J.S.; Sayeed, V.A.; Bryant, A.; Habib, M.J.; Khan, M.A. Tablet splitting of a narrow therapeutic index drug: A case with levothyroxine sodium. AAPS Pharmscitech 2010, 11, 1359-1367. [CrossRef]

196. Mosena, M.S.; Van der Merwe, E. The appropriateness and risks of tablet splitting: Medifile: Clinical review. SA Pharm. J. 2009, 76, 30-36.

197. Gordon, M.S. Process considerations in reducing tablet friability and their effect on in vitro dissolution. Drug Dev. Ind. Pharm. 1994, 20, 11-29. [CrossRef]

198. Alkan, M.; Yuksel, A. Granulation in a fluidized bed II Effect of binder amount on the final granules. Drug Dev. Ind. Pharm. 1986, 12, 1529-1543. [CrossRef] 
199. Campbell, C.S.; Brennen, C.E. Computer simulation of granular shear flows. J. Fluid Mech. 1985, 151, 167-188. [CrossRef]

200. Fassihi, A.; Kanfer, I. Effect of compressibility and powder flow properties on tablet weight variation. Drug Dev. Ind. Pharm. 1986, 12, 1947-1966. [CrossRef]

201. Liss, E.D.; Conway, S.L.; Zega, J.A.; Glasser, B. Segregation of powders during gravity flow through vertical pipes. Pharm. Technol. Eur. 2004, 28, 78-97.

202. Malliaris, A.; Turner, D. Influence of particle size on the electrical resistivity of compacted mixtures of polymeric and metallic powders. J. Appl. Phys. 1971, 42, 614-618. [CrossRef]

203. Müller, M.; Albe, K. Lattice Monte Carlo simulations of FePt nanoparticles: Influence of size, composition, and surface segregation on order-disorder phenomena. Phys. Rev. B 2005, 72, 094203. [CrossRef]

204. Gauthier, D.; Zerguerras, S.; Flamant, G. Influence of the particle size distribution of powders on the velocities of minimum and complete fluidization. Chem. Eng. J. 1999, 74, 181-196. [CrossRef]

205. Narayan, P.; Hancock, B. The influence of particle size on the surface roughness of pharmaceutical excipient compacts. Mater. Sci. Eng. A 2005, 407, 226-233. [CrossRef]

206. Bolhuis, G.K.; Anthony Armstrong, N. Excipients for direct compaction-An update. Pharm. Dev. Technol. 2006, 11, 111-124. [CrossRef]

207. Reynolds, G.K. Modelling of pharmaceutical granule size reduction in a conical screen mill. Chem. Eng. J. 2010, 164, 383-392. [CrossRef]

208. Chikhalia, V.; Forbes, R.; Storey, R.; Ticehurst, M. The effect of crystal morphology and mill type on milling induced crystal disorder. Eur. J. Pharm. Sci. 2006, 27, 19-26. [CrossRef]

209. Yeh, A.-I.; Huang, Y.-C.; Chen, S.H. Effect of particle size on the rate of enzymatic hydrolysis of cellulose. Carbohydr. Polym. 2010, 79, 192-199. [CrossRef]

210. Ghasemi, M.; Alexandridis, P.; Tsianou, M. Conversion of particle size distribution data from mass to number-based and its application to biomass processing. Biosyst. Eng. 2018, 176, 73-87. [CrossRef]

211. Deveswaran, R.; Bharath, S.; Basavaraj, B.; Abraham, S.; Furtado, S.; Madhavan, V. Concepts and techniques of pharmaceutical powder mixing process: A current update. Res. J. Pharm. Technol. 2009, 2, 245-249.

212. Li, W.; Bagnol, L.; Berman, M.; Chiarella, R.A.; Gerber, M. Applications of NIR in early stage formulation development. Part II. Content uniformity evaluation of low dose tablets by principal component analysis. Int. J. Pharm. 2009, 380, 49-54. [CrossRef]

213. Lemieux, M.; Bertrand, F.; Chaouki, J.; Gosselin, P. Comparative study of the mixing of free-flowing particles in a V-blender and a bin-blender. Chem. Eng. Sci. 2007, 62, 1783-1802. [CrossRef]

214. Gyenis, J. Assessment of mixing mechanism on the basis of concentration pattern. Chem. Eng. Process. 1999, 38, 665-674. [CrossRef]

215. Sudah, O.S.; Coffin-Beach, D.; Muzzio, F.J. Quantitative characterization of mixing of free-flowing granular material in tote (bin)-blenders. Powder Technol. 2002, 126, 191-200. [CrossRef]

216. Jia, X.; Williams, R.A. A packing algorithm for particles of arbitrary shapes. Powder Technol. 2001, 120, 175-186. [CrossRef]

217. Portillo, P.M.; Ierapetritou, M.G.; Muzzio, F.J. Characterization of continuous convective powder mixing processes. Powder Technol. 2008, 182, 368-378. [CrossRef]

218. Escudie, R.; Epstein, N.; Grace, J.; Bi, H. Effect of particle shape on liquid-fluidized beds of binary (and ternary) solids mixtures: Segregation vs. mixing. Chem. Eng. Sci. 2006, 61, 1528-1539. [CrossRef]

219. Mendez, R.; Muzzio, F.; Velazquez, C. Study of the effects of feed frames on powder blend properties during the filling of tablet press dies. Powder Technol. 2010, 200, 105-116. [CrossRef]

220. Savage, S.; Lun, C. Particle size segregation in inclined chute flow of dry cohesionless granular solids. J. Fluid Mech. 1988, 189, 311-335. [CrossRef]

221. Rosato, A.D.; Blackmore, D.L.; Zhang, N.; Lan, Y. A perspective on vibration-induced size segregation of granular materials. Chem. Eng. Sci. 2002, 57, 265-275. [CrossRef]

222. Sinka, I.; Motazedian, F.; Cocks, A.; Pitt, K. The effect of processing parameters on pharmaceutical tablet properties. Powder Technol. 2009, 189, 276-284. [CrossRef]

223. Peck, G.E.; Baley, G.J.; McCurdy, V.E.; Banker, G.S. Tablet formulation and design. Pharm. Dos. Forms Tablets. Marcel Decker N. Y. 1989, 1, 75-130. 
224. Wilczyński, S.; Koprowski, R.; Duda, P.; Banyś, A.; Błońska-Fajfrowska, B. Microtomographic studies of subdivision of modified-release tablets. Int. J. Pharm. 2016, 511, 899-912. [CrossRef]

225. Gómez, D.A.; Coello, J.; Maspoch, S. Raman spectroscopy for the analytical quality control of low-dose break-scored tablets. J. Pharm. Biomed. Anal. 2016, 124, 207-215. [CrossRef]

(c) (C) 2019 by the authors. Licensee MDPI, Basel, Switzerland. This article is an open access article distributed under the terms and conditions of the Creative Commons Attribution (CC BY) license (http://creativecommons.org/licenses/by/4.0/). 